\title{
Critical Legal Histories
}

\author{
Robert W. Gordon*
}

Critical legal writers pay a lot of attention to history. In fact, they have probably devoted more pages to historical descriptionparticularly the intellectual history of legal doctrine-than to anything else, even law and economics. Such a preoccupation within a radical movement is at first glance surprising. After all, lawyers have, by notorious custom, used history conservatively, appealing to continuity and tradition. ${ }^{1}$ And in the less common situations in which lawyers have used history to criticize the status quo, they have usually resorted to social and economic history, to show that the original social context of a legal rule reveals it was adopted for wicked or obsolete reasons, rather than to the history of legal doctrine. ${ }^{2}$ What could conceivably be radical-or, as some unkindly ask, even interesting-about rewriting the history of doctrine?

I will attempt, in this article, to give a brief account of the impulses that have prompted the Critical scholars to their chosen ways of writing history (or rather histories, since the movement has actually spawned several different historiographical practices). I'll start by trying to describe a vision of law-in-history that has tended, as I'll

* Professor of Law, Stanford University. I am grateful to Paul Brest, Tom Heller, Fred Konefsky, Elizabeth Mensch, Deborah Rhode, Mark Tushnet, and especially to Steve Diamond, Lawrence Friedman, Tom Grey, Mark Kelman, Jack Schlegel, Bill Simon, and Dave Trubek for reading earlier drafts and suggesting revisions. Willard Hurst gave the manuscript his usual incredibly close attention, wrote a dozen pages of detailed comments, approved what he could with characteristic generosity, and vigorously challenged what he could not; this article continues a longstanding conversation with him. I owe a special debt to David Sugarman, who has generously shared his ideas with me for years and whose invaluable and (unlike this piece) copiously footnoted manuscript, Sugarman, Towards a Neu, History of Law and Malerial Society in England, 1750-1914, in LAW, ECONOMY AND SOCIETY: EsSAYS IN THE HistoRY OF ENGLiSH LAw, 1750-1914 (G. R. Rubin \& D. Sugarman eds.) (forthcoming), which arrived as I started to think about this article, has impressed its influence on every page.

1. Horwitz, Book Review, 17 AM. J. Legal Hist. 275, 275-76 (1973).

2. Doctrinal history has not always been conservative. Radical legal argument used to draw upon its own notions of the ancient constitution, which was to be reclaimed by revolution from a corrupt present. See, e.g., C. Hill, The Noman Yoke, in PURITANism and REVOLUTION: SOURCES IN INTERPRETATION OF THE ENGLISH REVOLUTION OF THE 17TH CENTURY 58 (1958). 
argue, to dominate liberal legal scholarship. I will then outline some of the Critical insights that have developed-many of them within liberal scholarship itself-to corrode separate components of that dominant vision. Next I'll show how Critical writers have tried to build these insights into a more thorough critique and how this critique has affected the ways in which they go about their work. Finally, I will discuss some common attacks on Critical histories, add a few doubting remarks of my own, and proffer some suggestions and exhortations for future directions. ${ }^{3}$

I have little hope, in the pages that follow, of making a new contribution to the longstanding debates over theory and method in socio-legal history. ${ }^{4}$ 'm really only concerned with summarizing, in what I would like to think is a clarifying way, some of the main positions in these debates, aware that the outcome of such an effort is bound to look like a seed catalogue or a Pocket Guide to the Common and Exotic Varieties of the Social/Legal Histories of North America. The audience I would most like to reach is that of liberal lawyers who are interested enough in Critical legal writing to be curious about it and who might find it more persuasive as well as more accessible if equipped with such a little guidebook. ${ }^{5}$

As the bulk of this piece is committed to describing criticisms of a tradition of historiography called "legal functionalism," I should also say that this is the tradition that has done most to nurture and in-

3. The knowledgeable reader will have noticed that this outline follows a format (orthodoxy synthesized-partial critiques-total critique and transcendence-critique of the critique) that has become almost as stylized in CLS work as the sonata form was in classical composition. Perhaps it's time for a new format.

4. Still less does this piece try to join the interesting controversies among Marxist historians and theorists. Although these controversies have counterparts in the literature of American legal scholarship, they are almost never referred to in that literature. Further, any attempt to describe the controversies would require introduction to a lot of specialized concepts and jargon. For a useful recent survey of these controversies, see G. MCLENNiN, MARXISM AND THE METHODOLOGIES OF HISTORY (1981).

5. Mine is hardly the first such guidebook. For exceptionally useful treatments of social/theoretical issues in legal historiography, see A. HUNT, THE SOCIOLOGICAL MOVEMENT IN LaW (1978); Friedman, Some Problems and Possibilities of American Legal Histon, in THE STATE of AMERICAN History 3 (H. Bass ed. 1970); Holt, Morton Honvilz and the Transformation of American Legal Histon;, 23 WM. \& MARY L. REV. 663 (1982); Scheiber, At the Borderland of Law and Economic History: The Contributions of Willard Hurst, 75 AM. HIST. REV. 744 (1970); Sugarman, Theory and Practice in Law and Histony: A Prologue to the Study of the Relationship Betureen Law and Economy From a Socio-Historical Perspective, in LAw, STATE, AND Society (B. Fryer, A. Hunt, D. McBarnet, \& B. Moorhouse eds. 1981); Tushnet, A Marxist Analyses of American Lau". 1 Marxist Perspectives 96 (1978); Abel, Book Review, 80 Mich. L. Rev: 785 (1980): Diamond, Book Review, 77 Mrch. L. Rev. 784 (1979); Feinman, Book Review, 78 MrCH. L. REv. 722 (1980); Horwitz, supra note 1. 
spire my own work and there isn't one of its insights, including those I have come to think mistaken, that I haven't found useful. Moreover, as is so often true of really good history, the best writing in this tradition is always grandly overflowing its conceptual channels; one could do worse than to keep trying to imitate the practices of the great functionalist figures even after one has stopped accepting their theories.

\section{The Dominant Vision: Evolutionary Functionalism}

\section{A. Common Threads}

Over the last 150 years or so, enlightened American legal opinion ${ }^{6}$ has adhered with remarkable fidelity to what, in broad conception, looks like a single set of notions about historical change and the relation of law to such change. Stated baldly, these notions are that the natural and proper evolution of a society (or at least of a "progressive" society, to use Maine's qualification") is towards the type of liberal capitalism seen in the advanced Western nations (especially the United States), and that the natural and proper function of a legal system is to facilitate such an evolution. (The words "natural" and "proper" stress the normative nature of the theory; deviations from the norm are both atypical and bad.) Let me try to break this very general account down into some more manageable pieces, the handful of propositions that compose its core. Readers will, I hope, understand that what I'm constructing is an "ideal type": a list of the propositions that one could expect most legal writers within the dominant tradition to accept most of the time, even if one could also expect that any individual writer would want to qualify or even violently object to one or two of them. ${ }^{8}$

6. I'm speaking here not of the work of professional legal historians but of the background assumptions about law-in-history that are present in mainstream legal scholarship generally.

7. See H. Maine, ancient Law: Its Connection with the Early History of SoCIETY, AND ITS RELATION TO MODERN IDEAS 21-22 (London 1861).

8. The danger in trying to set down such a list, of course, is that readers-especially the readers who believe that their own world view is the one about to be made into a target-will say, "Well, who accepts that? I don't know any legal writer who subscribes to that view, at least not in such a simple-minded form. Who exactly is Gordon talking about here?" One way to deflect this reaction in advance would be to offer a long list of passages from mainstream legal scholarship that exemplify these core propositions. This might indeed be done, but it would take a lot of space to do it, in part because these propositions are rarely found in the baldly explicit form in which they are stated here. They appear in conventional legal discourse more as diffuse background assumplions, seemingly too unproblematic to need spelling out. I have decided against trying to document my list in this fashion, less (I hope) out of 
1. "Law" and "society" are separate social categories, each describable independently from the other but related to each other

through various mechanisms of causal linkage.

Writers in the dominant tradition make an important, though usually silent, move even before they start saying anything substantive about law-in-history: They divide the world into two spheres, one social and one legal. "Society" is the primary realm of social experience. It is "real life": What's immediately and truly important to people, like desire and its fulfillment or frustration, goes on there. This realm is the realm of production, commerce, the market, the family. "Law" or "the legal system," on the other hand, is a distinctly secondary body of phenomena. It is a specialized realm of state and professional activity that is called into being by the primary social world in order to serve that world's needs. Law is auxiliary-an excrescence on social life, even if sometimes a useful excrescence.

Though law and society are separate, they are related. And the big theoretical problem for writers who see the world this way is to work out the secret of that relationship. Thus, they ask questions such as, "Is law a dependent or independent variable?" "Is everything about law-norms, rules, processes, and institutions-determined by society, or does law have "autonomous" internal structures or logic?" "If it has internal structures, do they enable it to have an independent causal effect-to act as a positive feedback loop-on social life?" Writers in the liberal tradition (like those in the Marxist

laziness than out of the expectation that the readers and writers of mainstream legal scholarship will simply recognize the propositions as belonging to the ordinary, taken-for-granted, common sense of that scholarship. To supplement this method of recognition, I actually did try in another article to give concrete examples of writers who accepted this set of views. See Gordon, Historicism in Legal Scholarship, 90 YALE L.J. 1017, 1028-45 (1981) (the dominant vision was there called "adaptation theory" and more sketchily described than it is here). And in this article I try to provide many more examples at appropriate points.

As for readers who do recognize their own views in my list of the core propositions of the dominant vision but think my account unacceptably reduces, caricatures, or distorts those views, I propose the following procedure: (1) Consider whether the view you want to defend is more accurately categorized as part of the "dominant vision" or as one of the numerous "critiques" of that vision that appear later in this article (it may be that you are really a critic, rather than an adherent, of evolutionary functionalism as I've described it); (2) if after doing that you still find yourself a defender of evolutionary functionalism, but of a far more refined and subtle variety than my caricature, ask yourself whether your variant is or is not vulnerable to the many critiques (it may be that the critiques are as good against the sophisticated as against the crude versions); and fnally (3) if you have isolated a strain of the dominant vision that you believe to be immune to the critiques (or, naturally, if you think the critiques are all garbage anyway), write a letter or publish an article in response to this one. 
tradition) have resolved these questions in wildly different ways and reached wildly different conclusions, ${ }^{9}$ but they all assume that these are the vital questions.

\section{Societies have needs.}

This proposition is the functionalist heart of the dominant vision. ${ }^{10}$ Social needs may be universal-needs such as survival, stability, maintenance of social order, conflict management, organization of production, security against foreign enemies, allocation of scarce resources, or preservation of continuity in the midst of change-or they may be specific to a given stage of social or economic development. One key need is the need to develop along the appropriate social evolutionary path.

Needs operate both as pressures and as constraints. They are the motors driving the society to find means for their fulfillment, and they set the limits on the possibilities of social experimentation-limits beyond which lie dysfunction, futility, failure, and chaos. ${ }^{11}$

\section{There is an objective, determined, progressive social evolutionary path.}

The general idea here is that the causal responsibility for change lies with impersonal forces of historical "becoming." More specifically, the histories of certain advanced Western societies, most notably the United States, describe an evolutionary development that is

9. See notes 18-26 infra and accompanying text.

10. This proposition is probably also the single most disputed one within liberal legat scholarship: Many writers see the attribution of "needs" to societies as excessively reifying, and they therefore try to break societies down into their constituent individuals or interest groups. See text accompanying note 38 infra.

11. For the purposes of this article, I'm reserving the term "functionalism" for the particular type of explanation outlined here, i.e., one that first posits a set of "primary," more-orless objective needs or dynamic processes and then explains "secondary" historical phenomena as responses to those needs or processes.

Some legal writers seem to use "functionalism" in a sense different from mine, to mean any way of explaining legal forms or practices by reference to social "purposes" or "interests"-indeed by reference to anything other than the formal, internal materials of the legal system. This usage seems to me both too broad and too narrow. It's too broad because any practice is "functional," and none dysfunctional, if that means it serves somebody's interest or can be seen as part of a system or pattern or process. And it's too narrow because it arbitrarily excludes attempts to show how the "function" of a legal practice might be to meet the formal requirements of (i.e., serve someone's "ideal interest" in) the elegance or completeness of an abstract system. I'd prefer to call this general type of explanation "external" or "contextual" and to label as "instrumental" the particular subset of external explanations that account for legal practices as products of the desires or demands of social classes, groups, or individuals. 
both natural (in the sense that some version of it will happen in every society unless "artificial" constraints force a deviation) and, on the whole, progressive.

Different generations have described this evolutionary process somewhat differently, but the contemporary United States almost always ends up sitting at the developmental summit. The great eighteenth and nineteenth-century story (the "Scottish Enlightenment" story ${ }^{12}$ whose general outlines are still so firmly rooted in our culture) told of the gradual liberation of the individual from the shackles of feudalism and superstition-from restraints on trade, on free alienation of land, and on free movement of labor; from the oppressions of feudal dues and tithes and of perpetual subordination to customary hierarchies of ecclesiastical and noble orders; and from established religions. According to this story, the concurrent spread of liberty and commerce yielded a commonwealth of men who were actually or potentially (with some exceptions such as slaves) politically equal property-holders, securely owning and freely exchanging land, labor, and capital. ${ }^{13}$

By the start of our own century, the growth of propertyless classes caused the historians' emphasis to shift away from the concept of progress as the growth of yeoman freeholders and towards the concept of progress as improvement in technology, organization of production, and creation of opportunities for immigrants to rise in society. In our own age of dampened enthusiasms, the labels attached to basic historical changes tend to be more neutral: "industrialization," "modernization," or just "political and economic development." In usage, however, these labels retain a strong normative flavor and occasionally, as in some legal economists' interpretation of the history of societies as one long series of "efficiency" gains, ${ }^{14}$ an unabashed Victorian optimism.

What all these histories have in common is their determinist tele-

12. See J. Burrow, A Liberal Descent: Victorian Historians and the ENGlish Past 21-35 (1981); A. Hirschman, The Passions and the Interests: Political ArglMENTS FOR CAPITALISM BEFORE ITS TRIUMPH 81-93 (1977).

13. The story was always ambiguous as to whether an ideal element (the love of liberty) or a material one (extension of the market) was the driving force behind this liberation.

14. One can take as an example the following statement:

The efficient society is wealthier than the inefficient-that is what efficiency means-and a wealthier society will support a larger population. This effect of greater wealth can be decisive in the competition among primitive societies, where the methods of warfare are simple and numbers of people count for much more than in modern warfare. Archaic societies sufficiently durable to have left substantial literary or archaeological remains and primitive societies sufficiently durable to 
ologies, whose elemental parts-the "extension of the market," the "breakdown of traditional communities and status hierarchies," the "shift from ascribed to achieved social status," the "triumph of the middle class," the "revolution of production in the factory system," the "rise of the administrative state," and the "development of the multi-divisional form of corporate organization"-are all linked together in a master process of social evolution. ${ }^{15}$

Lawyers once played a moderately important role in actually writing these histories. Recent legal writing is more likely just to assume that some objective, generally understood process of development has been working away in the background, and to leave the actual details of the process to vague implication.

\section{Legal systems should be described and explained in terms of their functional responsiveness to social needs.}

Functionalist sociological legal history has an exceedingly distinguished lineage, beginning with Montesquieu and Adam Smith, continuing through Karl Marx, Max Weber, and Rudolph von Jhering, and virtually all lesser nineteenth-century writers on law, ${ }^{16}$ and including among twentieth-century lawyers such figures as Oliver Wendell Holmes, Roscoe Pound, Karl Llewellyn, Franz Neumann,

have survived into the nineteenth century (when serious anthropological study began) are likely, therefore. to be societies whose customs are efficient.

Clearly, however, the primitive social equilibrium is less efficient, at least in the long run, than that of advanced societies: consider the very small proportion of the world's population that lives in primitive societies today. This situation is due in some part to coercion, rather than peaceful competition, from the advanced societies (dramatically so in the case of the North American Indians, for example), but in greater part to the adaptive responses of primitive society to its economic environment. These responses include practices, such as denying people privacy and preventing them from amassing wealth, which are inimical to economic progress and in turn to population growth. This is a point to give the romantic anarchist pausc.

Posner, A Theon of Primutuze Soctety, With Spectal Reference to Lau, 23 J. L. \& EcoN. 1, 53 (1980).

I suppose that if Suciety $A$ invents the Maxim gun, which it uses to massacre the natives of Society B, or develops an immunity to its own virulent venereal diseases, which then spread among and wipe out the population of Society B, we could say that Society A is more "efficient." Other adjectives also come to mind.

15. It was of course not a lawyer, but the sociologist Talcott Parsons, who produced the Summa of modern accounts of this integrated process. See, e.g., T. PARSONs \& N. SMELskR, ECONOMY aNd SOCIETY: A STUdY in the INTEgRation of ECONOMIC AND SOCIAL TheORY 284-94 (1956). Yet something like the Parsonian account is remarkably pervasive in modern legal scholarship though its optimism is occasionally qualified with a trace of tragic modernism.

16. See, e.g., P. Stein, Legal Evolution: The Story of AN Idea 122-27 (1980). 
and Willard Hurst. The general functionalist method is to construct (or, as is rather more common, to assume without much discussion) a typology of stages of social development and then to show how legal forms and institutions have satisfied, or failed to satisfy, the functional requirements of each stage. Obviously, an enormous gap in sophistication and conceptual power separates the best and worst examples of this method. At its best, as in Weber's work, complex bundles of rules are tied through explicit theorizing to elaborate accounts of social development. At its comically vulgar worst, the method produces wholly speculative functional rationales for legal rules in underlying social changes-vacuously described rationales such as "the evolution of the right of privacy was a response to the increasing complexity and interdependence of modern society." 17

Of all the generalizations produced by this method, one so familiar that it has become a cliché of our common discourse is that capitalist development (or as our forebears preferred to put it, the expansion of commerce) requires legal improvements that increase the certainty and.predictability of exchange relationships. I will come back to this assertion, but I should first list the final identifying characteristic of the dominant vision, namely:

\section{The legal system adapts to changing social needs.}

This concept expresses the confidence that, in the advanced Western nations and especially in the United States, the legal system has in fact responded to evolving social needs. Save for egregiously Panglossian writers (Blackstone in some moods is one of these), the proponents of this notion do not feel a need to attribute a social function to every piece of law in the system; most writers will concede that even major legal forms and processes can be dysfunctional for short periods. But a committed functionalist will maintain that, despite undeniable instances of lag and reaction, adaptation is the normal course. The perspective thus tends to produce statements such as the following (presented here for the sake of illustration in their simplest and most unqualified form), which discuss specific changes in legal rules or forms:

-Tort law rules such as the negligence standard and the fellowservant rule were adopted to meet the needs of early industrial development. (They allowed employers and transportation entrepreneurs to externalize a portion of their costs.) But as technological change

17. For a marvelous collection of examples, see Kelman, Trashing, 36 STAN. L. REV. 293 (1984); see also notes 53-60 infra and accompanying text. 
increased the risks of accidents stemming from employment and from the use of consumer goods, the law responded with rules of strict liability.

-Warranty rules such as "caveat emptor" reflected a society in which most commercial trading was face-to-face. But with the rise of mass consumer transactions between remote sellers and purchasers and with increasing ignorance about the risks of defects, the law implied warranties of merchantability.

- The corporate form developed in order to fulfill the need for capital accumulation during the period of industrial take-off.

- Various features of modern corporate organization, including the "business judgment" rule and the rules specifying areas of management "prerogative" exempt from collective bargaining, developed in order to give management broad discretionary decisionmaking power necessary for efficient maximization of profits in advanced industrial societies.

-Courts and legislatures were competent to handle the problems of regulating the early nineteenth-century economy of competitive individuals. By the late nineteenth century, however, the concentration of corporate enterprise was raising problems of such complexity that administrative agencies were required to handle them.

- Professionalization of the bar-the development of bar associations, law schools, formalized training and entry requirements, the large urban law office, etc.-was necessary to enable lawyers to take on the complex specialized tasks of law in a modern economy.

This perspective also produces some very large claims indeed. The first two examples listed below were commonplace in legal rhetoric through the end of the last century; the third is asserted by some lawyer-economists in our own time:

- The common law over time tends to work itself pure.

-Progressive improvements in legal science have tended to clarify legal doctrine, making it ever more certain and predictable, as well as more adaptable to social needs.

-Common law rules have tended to become more and more efficient.

\section{B. Divisions Within Functionalism}

By now it will be evident that my "dominant tradition" is a very broad umbrella, covering legal writers whose views on many issues differ radically, some of whom would be appalled to find themselves 
sharing even a limited-purpose category with the others. In particular, I mean to group under the common shelter of "evolutionary functionalism" both of the great antagonistic parties of modern American legal thought, labelled here for simplicity's sake "Formalism" and "Realism." Each of these parties has, I think, worked out contrasting visions of what social development consists of and how law has adapted to that development without disturbing the fundamental assumption of progressive adaptation that they hold in common. The parties have clashed instead over such issues as the definition of law and the autonomy of legal decisionmaking. ${ }^{18}$

The Formalist side has a very restrictive notion of law as judgemade law: "The legal system is the domain of the legal specialist; the legislature is in general not part of the legal system but a source of the goals that the legal system is to carry out."19 Legislation and usually administration as well are thus relegated to the "social" sphere of the great law/society dichotomy. On the Realist side, however, law is "what officials do about disputes," 20 or even more broadiy, the work of anyone, including the private bar, whose task is the administration of public policy.

Formalists and Realists also divide over the issue of the "autonomy" of legal decisionmaking processes in relation to political, social, and economic decisionmaking. Formalists think that it is both usual and desirable for legal decisions to follow an internal professional agenda such as "a taught legal tradition" 21 of the common law. The idea is that such decisions will best perform their social/functional task of adaptation if lawyers and judges are not thinking about society at all but only about perfecting their own craft, because a logic of liberty or efficiency is inherent in the practice of that craft. Realists think that this proposition is nonsense, that policymaking can't be socially functional unless it is self-consciously directed towards the satisfaction of social needs. Realists do, however, have their own no-

18. Incidentally, the fact that legal Formalism has been politically conservative and Legal Realism more liberal-reformist is only an accident of our recent history. It is easy to imagine a radical formalism, such as the French Revolution's program to remake society in accordance with abstract legal rights, or a conservative Realism, such as German historicism.

19. R. Means, Underdevelopment and the Development of lah: Corporations A.Yd Corporation LaW in Nineteenth-Century Columbia xii (1980) (footnote omitted). This book is an exemplary performance in the functionalist/evolutionist mode of legal history (lacking, however, the normative notions of progress common to that mode).

20. K. Llewelly', The Bramble Bush: ON OUR Law and its Study 20 (1951). For a clear idea of what Llewellyn meant by this famous phrase, see W. TWINING, KARL LLEWELLYN AND tHE REALIST MOVEMENT 148-52 (1973).

21. R. Pound, The Formative ERa of American Law 82 (1978). 
tion of legal "autonomy": Policymakers ought to be, and sometimes actually are, insulated from the immediate pressures of short-term political or economic interests so they can concentrate on their society's long-run needs. ${ }^{22}$

These differences lead to differing Formalist and Realist approaches to legal history. Formalist legal history focuses exclusively on the development of legal doctrine, while Realist legal history considers doctrine as one component of a general, if not always wellcoordinated, policymaking enterprise. ${ }^{23}$ Further, formalist legal history considers phenomena outside the legal craft as distorting judicial decisionmaking or as simply irrelevant to the important story to be told; the Formalist hero is the judge or treatise-writer who best clarifies doctrinal categories. Realist history, on the other hand, takes as its main subject the relations of function or dysfunction between law and major trends of social development; the Realist hero is the social engineer who masterfully wields law as an instrument of policy. ${ }^{24}$

Naturally these differences lead to fundamental disagreements about the course of recent history. For many Formalists, the high point of legal development was reached around the end of the nineteenth century when the ideal of the rule of law as primarily enforced by judges through an autonomous legal order was at its peak of influence. $^{25}$ But the Formalists' high is the Realists' low: At that time, abstraction from concrete social forces had put the legal system badly out of synch with the evolving requirements of society, and we only climbed out of this trough of dysfunction through the implementation of the policies of Progressivism and the New Deal. ${ }^{26}$

\section{Interlude for Questions AbOUT The PoInt of ThIS PROJECT}

Before going on to say something about the attacks that have been eating away at the evolutionary-functionalist vision of legal his.tory, it is worth pausing a moment to ask why anyone should bother

22. Sie, e.g., J. Landis, The Administrative Process $111-17$ (1938) (discussing why agencies were organized so as to insulate them from the administration that appointed agency officials).

23. See, e.g., W. HURst, The GroWth of American LaW: The LaW Makers 439 - 46 (1950) (adopting a broad view of law and of the tasks of legal history).

24. See, e.g., Hurst, Alexander Hamilion, Law Maker, 78 Coll'm. L. Rev. 483 (1978).

25. See generally 1 F. Hayek, LAW, Legislation, AND LiberTy: Rl Les and Order $94-123(1973)$.

26. See, e.g., W. HuRst, LaW and the Conditions of FrEedom in the NinetelenthCentury United States 84-108 (1956). 
to attack the vision at all. Social scientists who have heard previous versions of this piece wonder why I worry so much about evolutionism (our dominant vision's points 3 and 5 ) and functionalism (2 and 4), the mainstays of the liberal sociology of the 1950's; these views have been so thoroughly discredited in modern social theory, they argue, as to be left almost without serious defenders. On the other hand, some of my legal colleagues, who have spent their working lives trying to slay the Formalist hydra that is still powerfully present in legal-academic and professional thought generally, think it perverse and ungrateful to attack the Realist versions of functionalism. for these versions have proven to be the most reliable weapons against the dogma that legal forms can be understood apart from their social context: If the weapons are broken, won't the hydra stalk the law schools unafraid?

To the first question, the second is itself a partial answer: Evolutionary functionalism, in both the Formalist and Realist versions, has been kept going much longer in legal thought than in social thought generally. This isn't only because the law schools tend to pick up mainstream intellectual opinion ten to fifteen years late. The notion that law always is, or at least ought to be, functionally adapting to evolving social needs is so deeply embedded in standard legal speech that one isn't likely to make a legal argument of any length without at least mentioning it. This notion presumably persists because of its serviceability to the liberal idea of law as the neutral arbiter of social conflict: It tells the managers of the legal system that their basic instructions are specified by a social process outside of the legal system and that they have no responsibility for that process except to solve the technical problems of devising functional responses that will help rather than hinder it. Hence, the inevitable ambiguities of legislative command, prior case law, custom, or constitutional text need never force a legal system to the pain of political choice because its managers can always claim to be serving the logic of an historical process or immanent social consensus that exists beyond and prior to politics. ${ }^{27}$

27. For example, dominant visionaries argue that in "modern" or "developed" societies. innovations in technology and the organization of the work force are continually expanding the size of the total economic pie. Political conflict properly takes place only over issues of secondary importance, such as how the pie is to be divided; expansion is both the natural course of development for a modern society and something that is in everyone's interest. The joi of the legal system, absent (evidently misguided) authoritative political directions to the contrary, is to facilitate the needs of the production process (e.g., "efficient management." "industrial peace"), which by definition are universal needs rather than those of a particular faction or class. See, for a fuller description of this example, Stone, The Post-War Paradigm in Amencan Labor Lau, 90 YALE L.J. 1509, 1545 (1981). 
What's more, not only is evolutionary functionalism still a living force in traditional legal argument, it has in recent years received a terrific hormone boost from some of the fanciest and most interesting new work coming out of the law schools: the Chicago law and economics movement, ${ }^{28}$ Williamson's "transaction cost" approach to legal institutions, ${ }^{29}$ Bob Clark's explicitly evolutionary approach to the history of the modern corporation, ${ }^{30}$ and Selznick and Nonet's theory of "responsive law."

Perhaps by now the second question, "Why knock functionalism when it's been so good to you?," is on its way to being answered. Realist functionalism has unquestionably been a politically progressive and intellectually liberating force; it has moved us away from the occasionally useful but ultimately sterile studies of technical forms evolving in a cultural vacuum and from the idea that lawyers and judges will always and automatically do the most possible good through complacent inattention to the society in which they live. Its empirical investigations of the law "in action" have exploded forever the Formalist fantasy that a universal scheme of neutral, general rules controls equally and impersonally the discretion of every class and faction of civil society. We owe to the Realist tradition of scholarship most of our understanding of variations in the effectiveness of law according to the power and wealth of the people it touches or who seek to use it, of "legal pluralism" (the fact that real social life is prodigal of sovereigns-different governments, officials at different levels of government, "private" associations-each making its own brand of law in cooperation or competition with the others), and of the complexity and perversity of legal/social relations (how it so often happens that a legal form seemingly designed to strengthen A's at the expense of B's ends up wiping out A's and entrenching B's more immovably than ever). So much indeed have the Realist functionalists accomplished that it's hard not to sympathize with their resentment of Critics who seem to be trying to displace them just as

28. See, e.g. Priest, The Common Law Process and the Selection of Effictent Rules, 6 J. LEGaL STLD. 65 (1977); see also Goodman, An Econome Theary of the Erolutzon of Cimmon Lax, $7 \mathrm{~J}$. Leg.al STUD. 393 (1978): Rubin, Why Is the Common Law Effictent?. 6 J. Legal Stud. 51 (1977); Terrebone, A Strctly Evolutionan Model of Common Law. 10 J. LEGAL STLD. 397 (1981).

29. See O. Williamson, Markets and Hierarchies ANalysls and ANTItrl'st IMPLICATIONS (1975).

30. See Clark, The Four Stages of Capulalism: Reflectons on Intestment Management Treatises, 94 HARv. L. REv. 561 (1981); Clark. The Interdisciplunary Stud, of Legal Evolution, 90 YALE L.J. 1238 (1981).

31. See, e.g., P. Selznick \& P. Nonet, Law and Society in Transition: Toward RESPONSIVE LAW (1978). 
Law-and-Society studies are beginning to make a dent on the mainstream lawyers who, until recently, showed little more than scorn for Realist empiricism. "Must we always," the empiricists ask despairingly, "be patronized by lawyers with fancy theories in their heads and no respect for facts? Might not our movement be allowed its dialectical moment of supremacy before the tides of Critical negativity drag it away?"3?

The Critics can give this cri de coeur a straightforward answer: Any intelligent Critical approach will make use of the insights and empirical findings of Realist functionalism, ${ }^{33}$ but there are apologetic aspects even to the Realist versions of the dominant vision that the Critics feel compelled to resist. For example, by emphasizing law as policy, Realist functionalism almost unconsciously reserves even what it believes to be the very marginal opportunities for legal influence on the direction of social change to an elite of policymakers: Mass movements and local struggles are not ordinarily thought of as makers of legal change. ${ }^{34}$ Because it assumes a natural harmony of interests in the fulfillment of social needs, it has trouble seeing conflict as other than dysfunctional disturbance of equilibrium. And, with all regard for its heroic contributions, I believe its essential working assumptions misleadingly objectify history, making highly contingent developments appear to have been necessary.

The Critics' basic argument-elaborated more fully below-is that by taking the world as we know it as largely determined by impersonal social forces, evolutionary-functionalists obscure the ways in which these seemingly inevitable processes are actually manufactured by people who claim (and believe themselves) to be only passively adapting to such processes. ${ }^{35}$ If there are evolutionary

32. Trubek, Critucal Legal Studies and Empiricism, 36 STAN. L. REv. 575 (1984) is an especially useful statement of the differences, both real and supposed. between CLS and the Lawand-Society movement.

33. I give examples of such uses at text accompanying notes 61-71 infra.

34. How ironic it is that the country whose People, by their official ideology, have delegated only limited powers to their State; whose political origins lie in revolutionary protests organized by "the people out of doors," crowds explicitly claiming legal status and legitimacy: and whose history is so full of mass reform movements should have produced such a Tory legal literature, narrowly focused on official agencies, especially the courts, and almost completely indifferent to extra-institutional law-making. On the different conceptions of reform "within" and "outside" the "system" informing liberal and Critical thought, see Simon, Iistons of Practice in Legal Thought, 36 STAN. L. REv". 469 (1984).

35. For example, the functionalist lawyers who helped to design the ground rules regulating labor-capital conflict after World War II assumed that the expansion of the total economic pie (which was in everyone's interest) required unconstrained management discretion over investment decisions and general working conditions, leaving to resolution through col- 
processes in social life, they are processes whose logic is one of multiplicity, not uniformity of forms. The social nature of human beings reveals itself not through constant responses to their environments but through an astonishing diversity of cultural responses and, most remarkable of all, a repeatedly demonstrated capacity to reimagine their situations so as to generate novel responses still. ${ }^{36}$ We invent shorthand labels like "modernization" as a way of summarizing what has happened in and trying to generalize about the history of particular societies. Then, by a trick of the mind, we suddenly reify our label into a process that had to happen the way it did. The next thing you know, we start explaining the whole contingent miscellany of contemporary social practices (especially the nasty ones) as the natural outcome of the "modernization process." But if there is no such single process, there can't be any single set of functional responses to it either. Surely there are other ways of thinking about history that don't trap us into supposing we're permanently stuck with what we happen to be used to, with only the tiniest margins for maneuvering. The hope of getting out of that trap and of exploring the alternatives is what fuels the enterprise of criticizing the dominant vision.

\section{Partial Critiques: Variations on the Dominant THEME}

I call the sample of views that follow "partial" critiques because they remain faithful to many elements of the dominant vision while rejecting others. These critiques come from all colors of the political spectrum.

\section{A. Variation \#1: Collapse "Needs" into "Interests"}

This move is so common that it could be called a subtheme rather

lective bargaining only the residual issue of how to divide the resulting surplus. Critical historians treat this more or less unexamined background assumption of a relationship of social necessity (efficient production requires legal forms preserving managerial prerogatives) as an ideological practice that helped to produce social necessity because it suppressed alternative methods of governing production as unthinkable or unrealistic. Thus, in company with many other social actors, lawyers were more or less unwittingly reproducing the world they were used to-actually helping to create what they imagined to be the given, pre-existing "hard social reality" of the situation-because they were trapped in a functionalist logic that told them the basic conditions of the production process had to remain much as they already were.

36. See S. Gould, The Mismeasure OF MAN 324-34 (1981) (what is biologically determined is a brain capable of creative variation in its cultural environment); Geertz, The Impact of the Concept of Culture on the Concept of Man, in C. GeERTL, THE INTERPRETATION OF CULTUREs (1973) (the human species realizes its "nature" not through uniformity but diversity of cultural forms). 
than a variation of the dominant view. It consists simply of breaking down the universal category of societal needs into the particular conflicting desires or interests of society's members. The function of law then becomes that of responding to some balance of those interests.

This variation has an interesting history of appearances in modern legal scholarship. Towards the beginning of this century, a writer who identified the factional pressures behind the the creation of a legal form was usually describing either an abnormal and regrettable situation or one that had happened a comfortably long time before. Explaining the political and economic origins of old law was all right so long as you made clear that recent law had developed independently of all pressures save the "taught tradition" of the profession. If you did attribute a class or special-interest origin to contemporary law, you did so in order to condemn it. Thus, legal conservatives condemned wages-and-hours laws as "class legislation," and Progressives condemned judicial invalidation of such laws as caving in to the Interests at the expense of the People.

But with time and growing disillusionment with the regulatory welfare state, one could hear more scholars, of whom perhaps the most influential were Lawrence Friedman and Gabriel Kolko, explaining not just bad law but all law as the product of interest-group pressures. ${ }^{37}$ These writers were soon joined by the Chicago-school economists, the sires of the modern law and economics movement, in rapidly increasing numbers. And if today you hear a voice claiming that a legal rule was adopted because its adoption served the interest of some regulated industry, or that a complex procedure exists only because it makes money for the legal profession-explanations of a kind once despised by mainstream lawyers as the paranoid cynicism of Populist and Marxist vulgarisateurs - the voice as likely as not belongs to a right-wing economist. ${ }^{38}$

There are several different ways of characterizing the interests that law tries to satisfy. Right-wing economism says that interests

37. See, e.g. L. Friedman, A History of American Lall (1973); G. Kolko, The Triumph OF CONSER VATISM: A REINTER PRETATION OF AMERICAN Histor Y, 1900-1916 (1963).

38. See, e.g., Pashigian, Regulation, Preventive Law', and the Duties of Altomeys, in THE Changing Role of THE CORPORATE ATTORNeY 3 (W. Carney ed. 1982); Stigler, The Theon of Econornic Reguiation, 2 BELL J. ECON: \& MGMT. ScI. 3 (1971). The economist can afford this kind of candor about political pressures on law because he's got the suprapolitical norm of "efficiency" to fall back on. The left-wing writer, on the other hand, is much more likely to argue that the legal system is "relatively autonomous," not completely to be explained by this sort of influence. See notes 86-88 infra and accompanying text. 
are just the arbitrary desires of individual subjects, revealed through crude behavioral proxies such as "willingness to pay" or votes. This school has no theory at all of how such desires originate, except perhaps a vague notion that people in a given occupational or institutional role will want to maximize the interest the theorist casually attributes to that role. ${ }^{39}$ Centrist-liberal pluralism discovers what interests are by looking at the programs of organized groups and largely explains legal enactments as compromises among those interests. While this view is certainly a big advance over the view of society as isolated individuals or roles, its mainstream forms have been famously vulnerable to the charge of lacking any plausible account of power or social structure that would help explain why some groups get their way more than others.or why some groups never get to be "interests" at all because they can't organize. ${ }^{40}$ Finally, various economisms, not all on the left, do pay attention to power and social structure and explain law as the instrument of ruling groups. These last merit their own subheading and are treated under Variation \#2.

But before going on to the rest of the Variations, it's worth pausing to ask if this first one, the reduction of needs to interests, represents an intellectual advance over the dominant vision. In some ways it clearly does: By assuming that conflict is a normal feature of social interaction, this view focuses attention on the distributional struggles underlying legal enactment and implementation and helps to identify who wins and who loses from different regimes of law. It also encourages descriptions of law-in-society that are populated with individuals and groups with aspirations and strategies and that are thus more concrete than the frequently vague allusions to the impersonal background forces of development that serve as the primary motors of change in the dominant tradition. After long immersion in writing that grounds legal change in the ghostly pressures of evolving doctrines or in such causes as "increasing social complexity and interdependence," one feels an amazed and delighted gratitude at coming across an account that tells you that some piece of law took the form it did because a shipper's lobby, or homesteaders, or a coal company, or a Senate committee chairman wanted it to.

Almost needless to say, such accounts are often fatal to the nor-

39. For example, stockholders "want" profit on their investment and easy exit; workers "want" higher wages and benefits; neither "wants" a stake in management of the enterprise. (1981).

40. See Parker, The Past of Constitutional Theory-and zts Future, 42 OHiO ST. L.J. 223 
mative element in legal histories. ${ }^{41}$ Yet the switch from needs to interests is by no means all gain. For all its problems, the functionalist perspective recognizes that societies have to be understood as systems and structures, not just as a series of collisions among the preferences and strategies of their constituent members: All these people participate in and are constrained by structures of discourse, ways of thinking about reality and right, cultural inheritance, and political and organizational forms that shape desire and channel its expression. The subtler exponents of "instrumental" theories of law (as this Variation's theories are commonly called) have always recognized this. The more reductionist exponents, principally the economists, seem to think that one is puncturing all the vagueness involved in reifying "society" into a thing with "needs" by getting down to the nittygritty reality of concrete individuals and groups. But the "interest groups" of pluralist theory and the "individuals" of economic theory are no less reified and no more real entities than is the "society" of functionalists; they are just as much products of socially created and maintained categories of thought and conventional practices.

\section{B. Variation \#2-Transpose "Needs" into "Domination"}

In other words, every time a mainstream writer says a legal rule or process or institution serves the needs of society, show instead how it serves to maintain the power of a dominant class or group. Opponents of this variation are inclined to call it "Marxist," although the classical Marxist theory of law is just one highly specific subset of this variation. ${ }^{42}$ In reality, this general proposition would be adopted as well by many non-Marxists: by elite theorists, including conservatives like Alexander Hamilton, who think the ruling classes ought to control the legal system, and by fatalists, who think that for good or ill elites will always be in control and indeed that having control of

41. But not necessarily. It's quite possible, and indeed frequently happens, that a legal writer may combine an interest-group perspective with a functionalist one. The writer could argue, for instance, that needs appearing at some stage of historical development generate interests to assert those needs; the legal system then responds to those interests. Alternatively, the writer could take the view that the "market" for law-responsive-to-the-demands-of-interests tends toward a long-run equilibrium; and this view could (though it need not) be a normative one such as that of interest-group pluralism, in which the primary if not exclusive virtue of a legal system consists in its responsiveness to such demands.

42. The classical Marxist theory closely resembles the dominant liberal vision in that it holds legal institutions to be functionally responsive to the needs of the basic modes of production which define successive stages of a macrohistorical evolutionary process. For a useful summary account of the theory, see G. MCLENNAN, supra note 4, at 3-23, 45-65. 
the legal system is one of the things that helps identify those elites. ${ }^{43}$ On the other hand, modern marxisant theorists of law and the state, as well as most Critical Legal Studies people, have become so disenchanted with the project of trying to explain law as nothing more than the tool of the ruling class that their ideas can't be adequately treated under this subheading.

The great contribution of this variation has been to put social structure, class, and power-whose very existence much liberal legal writing seems so astonishingly to deny-back into our accounts of law. Histories of legal oppressions-of slavery, Indian Removal laws, Black Codes, labor injunctions-are indispensable reminders that there's often nothing subtle about the way the powerful deploy the legal system to keep themselves organized and their victims disorganized and scared. ${ }^{44}$ But the crude versions of the law-as-an-elite-tool theory are as vulnerable as mainstream functionalism to the critique which points out how incredibly difficult it is to relate events in the realm of "law" in any straightforward causal way to those in the realm of "society."

\section{Variation \#3-Weaken the Instrumental Links Between Law and Society}

Instrumentalist theories of law-which here include mainstream functionalism as well as the right-wing economics of Variation \#1 and the orthodox Marxism of Variation \#2-generally aspire to a positivist style of explanation. The idea is that someday (that Jubilee when all the data have been gathered in) we will be able to generalize convincingly and fairly abstractly about what social conditions will produce what legal responses and what effects upon society those responses will have in their turn. Yet I think it's fair to say that on the whole such statements of regularity in legal-social relations don't stand up very well to historical criticism. ${ }^{45}$ These statements keep

43. See, e.g., G. Mosca, The Ruling Class 130-34, 409-10 (1939).

44. An especially fine and subtle work in this genre is J. Gaventa, PowER AND POWERLESSNESS (1980) (describing use of terror, intimidation, control of the media, and manipulation of the legal and political processes in employers' campaign against striking Appalachian mineworkers).

45. This is a rather large assertion, for which thorough documentation would require combing mainstream legal scholarship for propositions suggesting functional linkages between legal forms and material conditions and then trying to show what was wrong with every such proposition. What I've done here instead is to pick out some commonplace examples of such propositions, all of them backed by respectable sponsors, in the supposition that they are representative samples of the whole bulk. Readers who think the examples are unfairly chosen are urged to produce better ones. 
running up against (a) comparative studies showing that social and economic conditions that are apparently similar in relevant respects ${ }^{46}$ have actually produced radically different legal responses and (b) demonstrations that the social effects of adopting a legal form are never predictable from the form itself, because the interpretation of a form, its enforcement by lower-level officials, and the response it's likely to elicit (enthusiasm, indifference, resistance) may all vary with the minutest particulars of context. ${ }^{47}$

Take, for example, the once familiar proposition that the negligence principle was a functional response to the social needs of industrialization in its earlier phases (because it protected infant industry by externalizing its costs onto farmers, workers, city residents, etc.). The problems with this proposition are that (a) lots of societies industrialized without the negligence principle or after the principle had been around so long that it could hardly be a "response" to industrialization, ${ }^{48}$ and (b) the fact that there was a "negligence principle" doesn't by itself imply any determinate set of social consequences because the principle can be interpreted (or ignored) by judges, administrators, jurors, or employers so as to produce any imaginable combination of liability and damages (including none of either). ${ }^{49}$

46. Of course one could argue that situations are never similar enough in type to afford a basis for such comparisons, but so strong a form of historicism would doom forever the possibility of a historical sociology of law along functionalist lines.

47. I should stress here that the most valuable criticism of this type has not come from radical critics, nor from CLS people, but from within mainstream liberal scholarship itselffrom (a) functionalist social theorists such as Weber, who conscientiously raise difficulties with their own positions; (b) legal historians such as Scheiber and Hurst, who seem to have a general commitment to the notion that law responds to social needs, but whose particular narratives undercut any strong version of functionalism by revealing how various the responses have been; (c) legal historians who tend to explain law as the product of interestgroup conflict, especially Friedman, who has always emphasized how many different techniques, legal or nonlegal, can serve an economic function and refused to give any legal form a position of causal necessity. See, e.g., L. FRIEdMan, supra note 37, at 234 ("It is doubtful that majestic capitalism would have smothered in its crib without the rule of caveat emplar. It is doubtful whether specific doctrines of commercial law were cause, effect, or condition of American capitalism; or all or none of these." (footnote omitted)); (d) institutional-economic historians, such as those cited infra note 62 , who have done comparative work on the role of the state in promoting and regulating economic development; (e) the work of the law-andsaciety movement on the "gap between law on the books and the law in action," stressing the study of implementation of legal rules; and finally ( $f$ ) the Legal Realists' critique of Formalist conceptualism, stressing the dependency of textual meaning on context and convention.

48. See, e.g., Rabin, The Historical Development of the Fault Principle: A Reinterpretation, 15 GA. L. REv. 925 (1981); Schwartz, Tort Law and the Economy in Nineteenth Century America: A Reinterpretation, 90 YALE L.J. 1717 (1981).

49. "There were and always are rules and counterrules, rules with exceptions of such scope as to threaten the rule itself, rules whose force can be eliminated by drawing creatively 
These signs of indeterminacy naturally do not daunt the committed functionalist; they only spur him on to more refined hypotheses that will account for most of the variations. But in practice the progressive refinement of general statements about causal relationships between legal and social forms tends rapidly to decompose such statements into the detailed histories of particular societies. One's brave and sweeping original hypothesis of the necessary relation between industrialization and a negligence standard of liability gets boiled down to something like this: "In those places where the negligence principle was recognized and routinely applied in a certain way, it may have helped somewhat to facilitate capital accumulation; in other places, where there seems to have been lots of capital accumulation under different legal conditions, (a) some other form served the same function as the negligence principle, or (b) for various special reasons it wasn't necessary to the accumulation process to have that function served, or (c) perhaps there would have been still more accumulation if there had been a negligence principle." There's nothing wrong with this modest sort of proposition; it's the common stuff of historical writing. But it is an awfully long distance from demonstrating that economic requirements produced the form and that it duly performed its functional services to those requirements. ${ }^{50}$

A Functionalist thus subdued can continue to argue for a scaleddown determinism: the legal forms that actually emerged in a particular society were necessary to that society's particular requirements. Even if a negligence rule was not necessary for industrialization, perhaps the fellow-servant rule, as administered to workers on the railroads or just the Pennsylvania Railroad in the 1870's, was critical to that industry's ability to finance its expansion. ${ }^{51}$ One can't disprove such an assertion. Because everything

on analogies to apparently unrelated areas of law, and so on." Tushnet, Book Review, 69 CORNell L. Rev. 281, 281 (1983).

50. Of course, lawyers or entrepreneurs of the time often believed that a given legal form was an indispensable condition of material progress or social stability and pressed for its adoption or retention because of that belief. But the historian who casts her project as that of reconstructing such beliefs has abandoned functionalism entirely for the historiography of legal ideology or consciousness. See Variation \# 7 infra.

51. R. FOgel, Railroads AND Economic Growth (1964) is an extended cliometrician's tour de force purporting to demonstrate that the raltroad itself was unnecessary to nineteenth century economic growth. The thesis is violently controversial, but the arguments in its favor are not trivial. And if a leading economic historian doubts the functional contribution of the railroad, are lawyers, equipped with perhaps one percent of that historian's technical sophistication and empirical data, likely to succeed in making the case for the functional necessity of the fellow-servant rule? 
that has happened in history is causally connected to everything else, there's no way to be sure that the connections were not forged by a logic of necessity. Even actions that seem chosen or simply accidental may just look that way because we haven't yet discovered the secret logic underlying them..$^{52}$ Yet, without for a moment disputing that the forms that industrial capitalism and the negligence principle took in the nineteenth-century United States might be related, is the evolutionary-functionalist hypothesis (law meets the needs of the developing economy) the most plausible means of relating these two things? It is here that the comparative data revealing all the myriad paths to capital accumulation and the legal-realist data revealing all the myriad permutations that a legal form undergoes in practice should at least make the functionalist hesitate.

Let me illustrate what I mean through what I mentioned earlier as probably the most frequently asserted functionalist proposition about law: the claim that various regimes of legal rules were necessary or at least very useful to capitalist development because they provided the certainty that facilitated rational calculation. The strongest versions of this claim propose, for example, that the rules of nineteenth-century contract law functionally responded to the need for certainty: When commerce summoned loud, "Thou must!," contract whispered low, "I can!" One hears this claim all the time, ${ }^{53}$ but it is very difficult to sustain. Such evidence as we have suggests that tracing the common law doctrines and institutions for enforcing contracts to businessmen, those whom one might expect to be society's preferred mouthpiece for voicing her needs, is very difficult. When businessmen say what they want from an enforcement mechanism, it's usually something along the lines of an arbitration process. ${ }^{54}$ To be sure, the legal system may have been wiser than the businessmen about their true needs: Lawyers undeniably thought so, as they liked to promote their products-the common law of contracts, treatises,

52. Compare, for example, the hypothesis that both the negligence principle and the organizational structures of industry were products of a common political/legal idcology" that liked to pretend that everything that happened in corporations was the product of voluntary individual choice.

53. The claim most recently appeared in P. ATIYAH, The RISE ANd Fall of FReEdom OF CONTRACT 420-24 (1979). This aspect of Atiyah's work is shrewdly criticized in Mensch, Book Review, 33 Stan. L. ReV. 752 (1981).

54. See, e.g., J. Alerbach, Justice Without LaW: Nonlegal Displte Setrtlement IN AMERICAN HISTORY 95-114 (1983); Feinman, Critical Approaches to Contract Lau, 30 U.C.L.A. L. Rev. 829, 847-52 (1983); Ferguson, Legal Ideology and Commercial Interests: The Soctal Origins of the Commercial Low Codes, 4 BRIT. J.L. \& Soc'Y 18 (1977); Sugarman, supra note *. 
Restatements, and commercial codifications-for their presumed tendency to "increase the certainty and predictability" of commercial transactions. Yet, in retrospect, the lawyers' goal of certainty appears to have been largely a legal fantasy. Formal rules framed in juristic categories, such as "offer and acceptance" and "consideration," that have no regard for the specific usages of real businesses are not predictable. Nor are rules phrased in terms of general standards of customary fairness, such as "reasonableness" and "good faith," so as to incorporate those usajges. And even if such rules were predictable, businessmen don't seem to pay much attention to them until the (rare) prospect of litigation looms. ${ }^{55}$

Further, when one looks at the early nineteenth-century legal system as a whole, rather than just at contract law, and to the system in operation, rather than just its formal doctrinal expressions, can one really say that this system made life more predictable for rational capitalist planning? Sometimes, perhaps. Other times, surely not. The law of that time, for example, rapidly divested a whole slew of previously vested legal rights-rights to monopolize resources, to enjoin nuisances created by new industry, to collect compensation for "indirect" property damage, and so forth. ${ }^{56}$ Should one therefore say, "The legal system was a functional response to the capitalist need to destabilize everyone's expectations, to put all property rights at the risk of devastation from competition or from exposure to spillovers from capitalist enterprise?" Early nineteenth-century governments also created commons out of large bundles of previously vested

55. See, e.g., Gordley, European Codes and American Restatements: Some Difficulties, $8 \mathrm{i}$ Colcs. L. Rev. 140 (1981); Macaulay, Non-Contractual Relations in Business: A Preliminary Stud, 28 AM. SoC. REv. 55 (1963); Gordon, Book Review, 36 VAND. L. REı. 431, 447-49 (1983).

Nax Weber, who wrestled with these problems more than anyone else, never claimed that lawyers, in creating these rules, were responding to the functional needs of capitalists. He argued instcad that lawvers were carrying out their project of legal rationalization for intellectual and status reasons of their own and that the culmination of their project happily coincided with the needs of capitalists for predictable rules. But the conscientious Weber had to back away from even this less deterministic, more cautious and more convincing theory of legal/social relations when he confronted the problem of England, a society with lots of capitalist development within an apparently woefully underrationalized legal system. This discovery led him to reflect that perhaps the practical-minded, business-oriented lawyers of England had devised a body of rules that was operationally more predictable than the highly formal rule-schemes of the Continent. Yet if that were so, his main thesis about the calculability of highly formal rule-schemes was itself thrown into doubt, as he himself acknowledged. For exceptionally good treatments of these aspects of Weber's work, see A. KRONMAN. MAS WeBER 118-25 (1983); Trubek, Max Weber and the Rise of Capitalism, 1972 WIS. L. REv. 720.

56. See M. Horwitz, The Transformation OF American Law, 1780-1860, at 31-62 (1977). 
individual entitlements, insisting on the community's power to subject property to takings or regulations for public uses. ${ }^{57}$ Should one thus say, "The legal system responds to the need to sacrifice individual expectations to capitalist needs for social overhead capital?" And what if one takes a closer look at what lawyers actually did for their commercial clients? One would find, it appears, that one of their main jobs in their roles as debt-collectors was to mediate in bad times between their creditor clients and the debtors, not pushing collection to the limit but trying to reschedule and scale down debts in order to keep everyone afloat until the upswing of the business cycle-in effect helping to redistribute losses among the whole trading community. ${ }^{58}$ Should one then conclude, "The legal system responds functionally to the needs of capitalism not to have legal rules enforced too strictly?" And one still has to account for what look like a large number of anticapitalist rules, such as those restricting corporate powers, capitalization, and attempts to limit liability. ${ }^{59}$ Perhaps here the explanation should be, "The legal system responds to the functional needs of capitalism to make concessions to its anticapitalist opponents." If one should be tempted to dismiss such rules (which I think would be a serious mistake) as aberrant spasms of dysfunctional Luddism, one can hardly do the same with the entire law of slavery or with the crop-lien system, which effectively tied farm labor to the land, that replaced it. ${ }^{60}$

It's worth repeating, since arguments like these are so often misunderstood, that this case for the indeterminacy of legal-economic relations is directed against certain typical propositions of relations of functional necessity, usually expressed in statements that some economic process "required" support from the legal system, which then responded to "meet the needs" of that process. The argument is not

57. See Scheiber, The Road to Munn: Eminent Domain and the Concept of Public Purpose in the State Courts, in 5 PeRspectives IN AMERICAN History 329 (1971).

58. See 1 The Papers or Daniel Webster 101-04 (A. Konefsky \& A. King eds. 1982).

59. See, e.g., J. Cadmasi, The Corporation in New Jersey: Business and Politics, 1791-1875 341-62 (1949); F. DODD, AMERICAN BUSINESS CORPORATIONS UNTIL 1860 373-90 (1954); J. HuRST, The LEgITIMACY OF THE BUSINESS CORPORATION IN THE LAW OF THE UNITED STATES, 1780-1970. at 12-57 (1970).

60. There is actually a fairly strong functional case for slavery's contribution to the capitalist economy, though it's not one that modern liberal lawyers often make. For one thing, slavery seems to have been quite an "efficient" system of production in itself, as well as the primary generator (through cotton exports) of the foreign exchange that financed Northern industrial development. For another, it was slavery that made it possible for whites to be the independent individual proprietors who are the heroes of the Scottish enlightenment story of the expansion of liberty and commerce. E. MORGAN, AMERICAN SLAVERY-AMERican FREEDOM (1975). 
that "legal" and "economic" practices bear no or purely random relations to one another (though many Critics doubt that these categories are very helpful). Regular, patterned, and moderately predictable (at least in the short-to-medium-term) causal relations are always springing up between specific legal and economic practices-though the lessons of Realism are that one has to get down to very concrete situations before one can describe what they are. These causal relations seem to contemporaries and to historians who study them later to work loosely together into some sort of system. Lawyers make their livings from their experienced insights into the operations of these patterns or systems; policymakers and investors make informed guesses, which are certainly not always wrong, that the patterns will continue to hold. This Variation's argument is that-though contemporaries and historians often believe the contrary-all the pieces of the system are very loosely articulated: Individual pieces, even quite large ones such as the fundamental premises of civil liability, the organization of enterprise in the corporate form, worker's compensation schemes, or even the progressive income tax, could have been even radically different without drastic consequences to the master social/economic processes that the functionalist has supposed to require them. The next Variation's argument is that the master social-eccnomic processes themselves could have been different, even radically different.

\section{Variation \#4-Turn Background Social Necessity into Contingency}

The preceding discussion pointed out the perils of matching legal responses to social needs: You end up having either to concede that the law has responded differently to the same needs or to multiply the number of needs in order to account for the differences. The first move calls into question the "functional" nature of the legal responses, the second whether it's useful to attribute "needs" to societies at all, especially needs emerging from the "logic" of some stage of historical development.

Let me illustrate this second point by continuing the example I used in my earlier discussion-the claim that legal rules promoted capitalism by providing certainty. The earlier discussion showed that it was dubious that the legal rules provided certainty at all. That is, the rules as implemented often did not have their intended effect. Further, there were many legal rules that actually created uncertainty. And the functional explanations for these rules involve 
a variety of hypothesized social "needs," which are sometimes conflicting.

The true functionalist, the functionalist sans peur et sans reproche, may at this point refine her theory so as to explain how all, or almost all, of these diverse legal phenomena meet social needs. ${ }^{61}$ But she may now slide into the position that law just satisfies particular interests, rather than broadly defined needs, unless she can somehow objectify her notion of needs. This task, however-the specification of a general legal sociology of economic development-will not be an easy one. For she will immediately run across highly evolved dynamic capitalist societies that got that way through (despite?) radically different government policies towards capitalist enterprise: refusal of subsidies for transport ventures, intolerance towards the corporate form, state-sponsored insurance of workers against the risks of unemployment and industrial accidents, coordination of major investmen $\hat{\imath}$ decisions through central bureaucracies, and promotion of social and political stability through legal reinforcement of the "feudal" rights of great agricultural proprietors. ${ }^{62}$ Of course, a nimble mind can invent a functional explanation for anything, reserving a residual category of "dysfunctional law" for the really tough cases, but such an explanation would hardly square with the original "predictability of transactions" hypothesis and would be in danger of falling into complete banality. Banality becomes pure tautology when the functionalist claim is reduced to one that the legal system responded to the needs of capitalism with rules securing to individuals large bundles of exclusion/exploitation/alienation rights that could be traded in markets because such a legal regime is one of the main characteris-

61. She may now say, for example, that a legal system that is responsive to the needs of capitalism helps to construct both the technological (e.g., subsidies and immunities to transportation networks) and institutional (commerce-clause-based demolitions of local trade barriers, negotiable paper, security devices, and corporations and partnerships to mobilize capital) infrastructures for the development of enterprise. Such a system also delegates major investment decisions to decentralized firms which are free to respond to market incentives: stabilizes entrepreneurial expectations but destroys rentier ones; builds in adjustment mechanisms to relax its rules when strict enforcement would pull everybody" down; pacifies opponents through strategic concessions, welfare palliations, or symbolic gestures; and so forth.

62. See, e.g., K. Barkin, THE Controversy over German Industrialization 1890-1902, passim (1970); C. Johnson, MITI and THE JAPANese Miracle: The Growth OF INDUSTRIAL POLICY, 1925-1975, passim (1982); C. Kindleberger, ECONOMiC GROWTH in France and Britain 1851-1950, at 183-208 (1964); A. Milward \& S. Saul, The DeVELOPMENT OF THE ECONOMIES OF CONTINENTAL EuROPE 1850-1914, at 318-22 (1977); Landes, The Structure of Enterprise in the nineteenth Century: the Cases of Britain and Germanj, in 5 R.APPORTS: COMIté INTERNATIONALE dES SCIENCES Historiques, XL CONGRès INTERNAtIONALE DES SCIENCES Historiques 107 (1960). 
tics most people use to define capitalism. ${ }^{63}$ But within that large definitional frame there have been many historical capitalisms. And there might have been thousands more still.

I won't spend much time on this point because an immense Critical literature has done the job. The governing idea of structuralfunctionalist sociology that all societies have needs to maintain equilibrium has been sufficiently battered out of countenance, and the grand evolutionary stage theories of eighteenth and nineteenth century social thought have been gradually picked to pieces. As I said before, legal writers have had too big an ideological stake in assuming that objective background forces supply the basic directives in social life to have contributed much to debunking such assumptions, ${ }^{64}$ but the whole debunking literature is at hand any time we want to tap into it. ${ }^{65}$ So let me leave this topic with a couple of quick examples of functionalist theories that assume objective social necessity and of the critiques that point out the contingent nature of that "necessity."

(1) Some legal writers have recently been captivated by Alfred Chandler's thesis about the emergence of large, vertically integrated, multi-divisional forms of corporate enterprise in the United States. ${ }^{66}$ This captivation is not surprising: Chandler's thesis in its most unqualified form perfectly suits the criteria of the dominant vision. It

63. The funny thing is that even the definition doesn't really fit the historical experiences from which it was extracted. Sugarman, Law, Economy, and the State in England, 1750-1914: Some Major Issues, in Legality, IDeology, and the STATe 223-30 (D. Sugarman ed. 1983) contains an especially useful discussion of the commonly held view that "absolute rights of property" are preconditions or defining traits of developed capitalist societies. These authors synthesize the results of many studies of English property, showing that property forms approached very close to absolute individual ownership in medieval times, and that a great diversity of restrictions and qualifications on property-holding forms persisted through late phases of capitalist development. See Kennedy \& Michelman, Are Property' and Contract Efficzent.: 8 HOFsTR. L. REV. 711, 764-69 (1980) (elegant demonstration that societies claiming to give full legal protection to private property and freedom of contract will also be found to legally promote (l) zones of unrestricted "states-of-nature," in which people are privileged to destroy one another's property at will (e.g., competition), and (2) commons, in which wealth is owned collectively and people are forced to share in gains and losses).

64. There are distinguished exceptions. See, e.g., 1 F. Pollock \& F. Martland, ThE History of ENGLISH LAh 627-34, 653-57, 669-78 (1895) (confounding the conventional wisdom on the evolution of property from communal to individual forms by asserting the "individualism" of medieval property).

65. For a representative sample, see the works cited in notes 1-4. See also Appleby, Modemization Theory and the Formation of Modem Soctal Theores in England and America, 20 CoMP. STuD. IN SOC'Y \& HIST. 259 (1978) (discussing the different ideologies of "modernization" adopted in England and America and the consequences of those differences for politics, economic policies, and social change).

66. See A. Chandler, The Visible Hand (1977). 
hypothesizes that these developments in the corporate form are functional responses to a set of objective-sounding, universalizable, historical conditions (the attainment of a given stage of development of technologies and markets). But Chandler has taken his evolutionary model abroad and found that, in various European countries at roughly comparable stages of market and technological development, many of the features of American managerial capitalism were missing, though some of them did show up much later, after World War II. ${ }^{67}$

A determined evolutionist wouldn't be upset by this discovery; she'd just attribute the late developments in the European experience to an evolutionary "lag" 68 and invent some ad hoc special reasons for the missing ones. To his credit, Chandler is not content with such a solution. He concludes instead that the differences are not entirely attributable to flaws or deviations in the development of European capitalism: They stem at least in part from differences in "cultural attitudes and values, ideologies, political systems, and social structures."69 The reason that this full range of complex variables wasn't used in the first place to explain the American experience (and it wasn't; there is literally not a word about culture or social structure in The Visible Hand, and only a few sentences about ideologies and political systems) is that Chandler is committed to the determinism of "organizational imperatives." He thinks of the other factors as affecting only the design details of the functionally mandated prototypical form in different societies: You can take it with or without options. soup it up or make it ride low; but these alterations are, as Marxists say, "superstructural": Underneath them all is the same old Chevy. One could have no quarrel with a method that combined the various elements of the American experience into an "ideal type," a model of organizational change self-consciously constructed for the sake of comparative study; but there's a huge difference between finding model explanatory patterns and reifying them into immuta-

67. See Chandler, The Linted States: Seedbed of Managerial Captalism, in MANAGERLAL HIerarchies: Comparative Perspectives on the Rise of THe MOdern Ind'strial ENTERPRISE 37-39 (A. Chandler \& H. Daems eds. 1980).

68. To me, however, a more promising sort of explanation might be found, for instance, in the political/ideological/cultural reasons why French entrepreneurs resisted copying Americans before. but not after, World War Il. See generally R. KL'ISEL. CAPITALISM AND THE ST.ATE IN MODERN FRANCE (1981) (discussion of French economic management in the twentieth century).

69. Chandler, supra note 67 , at 39 . To give due credit to Chandler and the history-ofentrepreneurship school from which he descends, they have always avoided the causal reductionism of economic history as the rational maximizing of everything. 
ble laws of historical development. The illegitimate move, the move that turns history into apologetic ideology, is to start supposing that one's ideal/typical pattern, actually made up of thousands of tiny contingent practices, represents a universal historical force.

(2) There are two basic kinds of determinist stories now circulating about the evolution of legal/social forms for the organization of the labor force in modern American society. The first of these, now much in vogue among lawyer-economists, stems from neoclassical theories of the firm and "transaction-cost" economics. It theorizes that rational profit maximizing fuels the search for cost-reducing innovations in organizational form as well as in technology. In this account, the various hierarchical arrangements that have been used to organize the work force appear as successions of progressively more efficient methods of lowering costs of production, such as the cost of monitoring workers to see they are doing as they are told. ${ }^{30}$

The other main determinist story comes from the counter tradition, now almost as venerable as the first, of Marxist accounts of industrial capitalism. A school of modern historians following the lead of Harry Braverman's pathbreaking work ${ }^{11}$ has transposed the optimistic theme of cost reduction into the dark minor key of domination. For these historians, the evolution of work organization is the story of the breaking of skilled workers' control over the labor process in the late nineteenth century and of the inexorable homogenization of labor through the deskilling of jobs. As it is for the complacent functionalists, a historical logic is at work here: not the logic of cost reduction but the logic of the subjugation and degradation of labor under the conditions of monopoly capitalism.

If forced at gunpoint to choose between these two stories, one should probably choose the second, if only because it's backed up by historical research into a lot of real industries, job reorganizations, and labor struggles: it has not been generated, as the first largely has,

70. See, e.g., Williamson, The Organzation of Work: A Comparatute Instztutronal Assessment, 1 J. ECON. BeHAl. \& ORg. 5 (1980). This story is the latest in a series now over wo centuries old of complacent functionalist accounts of how it's best for everyone that workers are treated as they are in industrial societies. It even seems to be on the point of displacing its immediate predecessor, the Weber-Parsons-inspired industrial sociology explaining how the specialized work tasks and bureaucratic hierarchies of modern production are results of the progressive "rationalization" of social life in modern society. (The sting in this sociological traditionWeber's own horror at the claustrophobic imprisonment of the frecdom of creative movement in the "cage" of rationality-was carefully drawn before export.) Sec also Kennedy, Cost Reduction Theony as Legitmation, 90 Y'ALE L.J. 1275 (1981) (discussion of the politics of this evolutionary world).

71. See H. Braverman, Labor and Monopoly Capital. (1974). 
a priori out of a formal model with only a casual smattering of allusions to the abundant empirical literature. The "efficiency" story is also vulnerable on other grounds. For instance, many of the specific features of early twentieth-century work organization, such as artificial job ladders fragmenting similar jobs into hierarchies of different grades or the recruitment of many different ethnic groups followed by the minute subdivision of departments by race and ethnicity, seem far more plausibly explained as designed to divide and subjugate the work force than to reduce costs. Indeed, contemporaries often observed that preventing labor from organizing was management's purpose. ${ }^{72}$ In any case, the general thesis that hierarchical forms of work organization are more efficient because they reduce transactions costs is oddly inattentive to the possibilities of the counter hypothesis that the best way to minimize costs of supervision might be to delegate tasks to people you trust with lots of discretion to work out the details of the job on their own, or for that matter, to have them design the tasks in the first place. ${ }^{73}$.

Yet the story of the degradation of work under the logic of monopoly capitalism has problems of its own. That logic, if it was there at all, worked itself out in remarkably various forms. Many studies of specific labor-management struggles have appeared since Braverman wrote, studies that have stressed the importance of the relatively underdetermined variable of working-class solidarity, trying to explain why that consciousness (which itself wasn't one thing, but lots of different things, with different cultural/religious/political roots) emerged in some settings rather than in others and how its presence and the variant forms it took affected the counter strategies of employers and the resultant capital-labor bargain. ${ }^{74}$ In addition, some of the most impressive studies we now possess. the historical contributions of the segmented-labor-market economists, tell a more

72. For discussions of these explanations, see Marglin, What do Bosses Do?. REv. R.aDlCAL Polit. Ecox.. Summer 1974. at 60: Stone, The Origin of Job Structures in the Sted Industr: RET. RADIKal PoltT. ECON., Summer 1974, at 113, 127-51; see also D. GoRdon. R. EDWARDS \& M. REICH, SEgMeNTEd WORK, Divided WORKERS: THE Historical TransforMATION OF LABOR IN THE UNITED STATES 112-64 (1982) (summarizing the evidence of this phenomenon).

73. For some interesting empirical support for this counter hypothesis, see, e.g., S. Bowles. D. GORDON, \& T. WeIsSKOPF, BEYOND THE WASTElaNd 122-78 (1983) (on high costs of centralized supervision of the workforce); A. FOX, BEYOND CONTRACT: WORK. Power AND TRL'St RELATIONS 66-119 (1974) (on the importance of trust in workplace organization): C. SABEL, WORK AND POLITICS 220-31 (1982) (on emerging alternatives to "Fordist" ways of organizing production in decentralized quasi-"cottage" industries).

74. Sec, eg., H. Gutman, WORk, Cllture aNd SOCIETY in INDL'strializiNG AMERICA (1976): D. MONTGOMERY, WORKER' CONTROL IN AMERICA (1979). 
complex story than Braverman's, one in which employers found the strategy of controlling labor by degrading and homogenizing jobs increasingly futile by the 1930's and then promoted the reskilling of certain jobs into an "independent primary segment" of privileged labor, thus both registering concessions to the gathering union movement and effectively limiting its spread. ${ }^{75}$ Finaliy, a glance at the comparative evidence casts the usual doubts on whether any single set of forms is required to serve a given social function. If the goal was to pacify labor movements, other means might have served than the degradation of work. The companies could have co-opted the unions through co-determination, or got the state to fold the unions into a tightly controlled junior role in a corporatist partnership, or treated labor as a fixed rather than variable cost and given workers stable wages and secure jobs in return for their undeviating discipline and loyalty. ${ }^{76}$ Or, for that matter, the unions might actually have won a measure of control over the labor process that satisfied at least some of their aspirations for honorable work at a decent wage. The unions didn't win what they hoped for, and one can suggest many reasons why they didn't (including lots of reasons having to do with law and the legal system), but the closer one looks at the process, the harder it is to find an inexorable logic to it.

\section{E. Variation \#5-Fill the Vacuum Left by the Collapse of Functionalism with Disengagement, Legitimating Ideologies, or Symbolic Ritualism}

Now that historical experience has turned out to be too prodigal of multiple developmental paths and of multiple legal adaptations to those paths for the comfort of traditional functionalist explanations, where can one turn in the hope of finding some coherent explanation of law-in-history? One possibility I've mentioned already: Explain anything that happens in the legal system by referring to someone's interest (Variation \#1). This method, subtly employed, yields narratives that are both subtle and exciting, but sooner or later, as every legal change is attributed in turn to a different set of bargains among interests, as a form of explanation it's going to seem discouragingly ad hoc. Moreover, one must at some point deal with what's known

75. See D. Gordon, R. Edwards \& M. REICH, supra note 72.

76. For a useful analysis of mixed strategies of repression and co-optation adopted by European states, see C. MaIER, RECASTING Bourgeois Europe 19-225 (1975); for the Japanese variation, see Levine, Labor Markels and Collective Bargaining in Japan, in THE STATE AND ECONOMIC ENTERPRISE IN JAPAN 633, 647-49 (W. Lockwood ed. 1965). 
as the "autonomy" problem-the fact that legal norms and practices aren't completely plastic and don't alter every time another set of interests gets its paws on them because they do have some resilience, some long- or medium-term continuity of inner structure. ${ }^{77}$ Indeed, one of the properties that makes them legal norms and practices is that they at least appear to stand aloof from the everyday conflicts of civil society and to provide stable structures for the mediation of those conflicts. The classic preoccupation of legal sociology has been to try to pin down what's in this "autonomous" realm and theorize about its relation to the rest of society. I present three theories that are especially relevant to the background of the Critical approaches to legal history.

\section{Disengagement.}

By "disengagement" I mean beating a retreat to the position that although law is something that happens within societies, it doesn't have any important relations with the rest of society. Law is a realm of its own with its own history and categories and professional habits, and the only other thing you can compare. it to is another legal system. You can't hope to explain anything that goes on in it except by reference to its own peculiar internal details or to its borrowings from the details of other legal systems. ${ }^{78}$

77. If - just to focus on the most dramatic instance-one wants to explain the content of the Federal Constitution, the Beardian method of analyzing the class positions and financial stakes of the Framers is a perfectly valid first approach to the task (however snottily it may have been treated by people who wince to see sacred writings traced to material interests). But I think most people would now concede that this method yields results of strictly limited value and that one can understand the framers' projects much better after trying to reconstruct the general political language-the categories of thought and the basic assumptions about reality-in which the Constitution was written. Compare C. BEARD, AN ECONOMIC INTERPRETATION OF THE CONSTITUTION (1913) with G. WOOD, THE CREATION OF THE AMERICAN REPLBLIC, 1776-1787 (1969).

In some of the very best recent work in legal history, even writers thoroughly committed to placing legal forms in social and economic context have stressed how important it is to understand the internal structures and logics of such forms on their own terms. See, e.g., McCurdy. Justice Field and the Jurisprudence of Govemment-Bustness Relations: Some Parameters of Laissez-Faire Constitutionalism, 1863-1897, 61 J. AM. Hist. 970 (1975); Scheiber, The Road to Munn Eminent Domain and Public Purpose in the State Courts, in 5 Perspectives in American History 329 (D. Fleming \& B. Bailyn eds. 1971).

78. The "disengaged" have this much in common with the old Formalist doctrinal historians; but they've lost the Formalists' confidence that it's the very aloofness of law that gives it central importance as the functional mainstay of the unfolding norms of property and liberty. Our modern disengaged are a chastened bunch. Alan Watson actually subscribes to the dominant vision's basic functionalism but believes that the legal system's imperviousness to any but professionally ingrown practices makes it perpetually dysfunctional. See A. WATSON, Society AND Legal Ghainge (1977); see also Abel, Book Review, 80 Mich. L. Rev. 785 
There are grave problems with this approach. For one thing, as legal sociologists like Friedman and Macaulay point out, these writers, writing about the insular lawyer's law of cases, seem to be talking about awfully tiny corners of the law in any age (compared to legislation, administration, decrees, local law and custom, etc.) and especially in the current age of statutes and regulations. ${ }^{79}$ If this is the only "law" that legal intellectuals are going to write about, they will weirdly and incomprehensibly restrict their field to topics that, at least by their own hypothesis, aren't very important to anyone, including lawyers themselves, who actually spend most of their time dealing with statutes and regulations.

More seriously, I believe that disengagement is an obscurantist approach to the autonomy problem. First, autonomy in my original sense of long-run structural characteristics that make legal practices outlast short-term swings in political pressure is hardly unique to lawyer's law. Entire subdisciplines are committed to studying the

(1982) (dissecting not only Watson's thesis but legal functionalism generally). Charles Fried has lost some of his old conviction that legal rules were derivable from Kantian norms and now seems inclined to think that law doesn't resonate with anything but its own "artificial reason," and that law's social role is modestly confined to filling in the residual details of regulatory schemes in the course of settling marginal disputes. See Fried, The Art?fical Reason of the Lau: or What Lawyers Know, 60 TEX. L. REv. 35 (1981). And Richard Epstein has recently written a very good (except for its failure to acknowledge any of the work of the lawand-society movement, which has been making similar points for years in the Law and Society Review) piece on how common law rules don't seem to have any important social consequences and are therefore best understood as belonging to the transhistorical discourse of a peculiar fellowship of specialists, those charged with resolving those minor problems that occasionally get tossed to the courts. See Epstein, The Social Consequences of Common Law Rules, 95 HARV. L. REV. 1717 (1982).

I can't help believing-though of course I can't even begin to prove it-that the strategy of disengagement is partly a reaction to left-wing work (especially Morton Horwitz's. see M. HORWITZ. supra note 56, and to a lesser extent Douglas Hay's, see Hay, Property, Authority and the Criminal Lau', in Albion's FatAl TREe: CRIME AND SOCIETY' IN EIGHTEeNTH Century' ENGLANd 17 (D.Hay, P. Rule, P. Linebaugh \& E. Thompson eds. 1975)) that depicts law as an instrument of rulıng-class authority; it's the reaction of mainstream scholars saving indignantiy, "Well if that's the social meaning you're going to give to law, we're going to show it doesn't have any at all." Years earlier, Roscoe Pound had the same reaction: confronted with theories that tort law served the capitalist class, the one-time functionalist retrcated to the stance that tort law was a lawyer's creation irrelevant to anyone's needs. See Pound, The Economic Interpretation and the Law of Torts, 53 HARV. L. REV, 365 (1940). Another way of attacking the thesis that law serves the interest of ruling classes is, instead of disengaging law from outside influence altogether, madly to proliferate outside influences, so that every interest gets a crack at shaping the legal system. The "ruling-class-influence" is then buried under an avalanche of other variables.

79. See, e.g., Friedman \& Macaulay, Contract Law and Contract Teaching: Past, Present, and Future, 1967 Wis. L. REv 805 . Friedman and Macaulay do agree with the disengaged that some law is autonomous lawyer's law and, to that extent, it is socially trivial, being the "law of leftovers" that nobody cares enough about to regulate in some other way. 
autonomous characteristics of state structures such as bureaucracies and armies to show how constraints of organizational forms, ingrown traditions, professional ideologies, etc. affect how political agendas are formed, options perceived, urged, or suppressed, and so forth. ${ }^{80}$ Just as Realism taught us that judging, like legislation and administration, was political policymaking, it ought to have taught us that legislation and administration were, like judging, relatively autonomous. ${ }^{81}$ Thus, focusing on the autonomy of law to deny its relevance seems somehow unsupportable.

Second, I find it very hard to believe that autonomous legal forms are best understood as the product of a culturally isolated tribe of beings. Would any society tolerate lawyers as mediators of disputes, practical problem-solvers, or instruments of legitimate rule if the lawyers' practices didn't resonate at all with anyone else's? It seems much more probable that the specific legal practices of a culture are simply dialects of a parent social speech and that studying the speech helps you understand the dialect and vice-versa. Even a legal system clotted with arcane technicalities is unlikely to depart drastically from the common stock of understanding in the surrounding culture in the methods it uses to categorize social realities, the arguments about facts and values that it recognizes as relevant and persuasive, and the justifications it gives for its exercises of power.

80. See, e.g., T. Skocpol, States and Social Revolltions (i979). I mean to say: much more here than that bureaucrats and legislators have their own "interests" that sometimes cut across, warp, or neutralize. the pressures of "outside" interest groups. I mean that, like courts, bureaucracies and legislatures develop commitments to "doctrines" and "principles"--that is, to relatively abstract clusters of concepts that constrain their imaginations and actions. I really think it's pure lawyers' conceit to suppose that courts are fundamentally different in this respect from other legal institutions. True, our upper courts by tradition are supposed to be more self-conscious and to publish at least the formal reasons for their decisions. Yet if "autonomy" means, among other things, demonstrated capacity to stick to internal priorities and settled ways of thought in the face of intense short-term political pressure, isn't it likely that, say, the doctrines of the Pentagon's procurement and strategic planning establishments are at least as "autonomous" as those of most appellate courts? Mavbe even more so, because these establishments have more effective ways of suppressing dissenung opinons for many useful examples of "autonomous" bureaucratic practices, see THE POLITICS of Regt Lation (J. Wilson ed. 1980).

81. In fact, the Realists never got that far because most of them turned out to be stuck as fast to the case-law tarbaby as their Formalist predecessors. It may not be an exaggeration to say that the relative inattention (despite honorable exceptions and what looks like a growing interest in such subjects) to the "deep structures" cutting across diverse substantive fields of legislation and administration is the major disgrace of modern legal scholarship. But I would want to see such studies carried out nol on the ground sometimes urged by my law-andsociety friends. that because appellate cases are freaky and exceptional legal scholars should write about more typical legal products, but on the ground that such other products are in essential respects no different from appellate cases. 
The position of the disengaged seems to me to rest on two confusions. One is the confusion of a possibly valid methodological precept with a wholly invalid social theory. The precept is that when you want to account for a legal form, you should start your search for explanations in legal materials. This precept makes sense because the form is bound to be embedded in a whole contextual structure. For example, if you want to know what Cicero meant by "the public good" it's a good idea to look for other uses he makes of the phrase, what he contrasts it with, and how other lawyers use it. The theory is that discourse that is autonomous in this sense must therefore be peripheral or irrelevant to everything else going on in the society. But this theory doesn't follow from the precept at all. It's like saying that because Cicero has a specialized usage of "the public good" his usage must not have anything to do with contemporary Roman political controversies. 82

The other confusion is between law as particular enactments or events and law as clusters of practices and packages of enactments, processes repeated not once but many times over. Law in the sense of isolated enactments, decisions in a single case, or one proposition on page 351 of a hornbook, is rarely of any immediate instrumental significance. ${ }^{83}$ Epstein is surely right to claim that a few contract or tort rules more or less in the nineteenth century wouldn't have mattered

82. Sometimes one even hears legal historians argue for a method on the basis of the precept alone, claiming that since lots of law has a high technical content, the discipline of legal history should be confined to explicating the content that lawyers best understand. But "stuff outsiders can't understand" cannot be seriously proposed as a useful category for the study of social life, especially since laymen do come regularly into contact with these particular bundles of esoterica. At best, this very narrow view might be appropriate for people who saw their competence as purely auxiliary, similar to numismatics, epigraphy, or "quantitative and statistical methods." As legal specialists, they would stand ready to act as technical advisors to real historians. But the most insular of legal historians, far from being anxious to attach their specialties to general historiography, don't pay any attention to it at all!

83. This statement itself is confused. There really isn't any such thing as an isolated enactment. Every case or statute is just one event in a complex series leading up to and away from that event as well as a piece of the giant puzzle-structures of social interpretation that categorize the event and give it a meaning in relation to other "like" and "unlike" events. Hence, it's not a little misleading to speak of the "effect of a legal rule" as if the rule were just a single blip on the legal grid; the rule-event wouldn't have happened at all if people in the sociai sphere hadr't been preparing for it in some way. Much legal enactment just "ratifies" conventions that have already crystallized in social relationships. By the time the rule appears, the social struggle to produce it is already over, so the enactment doesn't appear to have any "effect." For an example in the context of family law, see Friedman, Law Reform in Historical Perspective, 13 ST. Lours U.L.J. 351, 362-64 (1969) (passage of the Married Women's Property Acts). 
much to anyone. ${ }^{84}$ But the whole complex of contract, tort, and property rules? The whole apparatus of debt collection? Slave codes and fugitive slave laws? One might suppose, without falling back into the functionalist position that all this law had to exist in order to serve the needs of basic economic or evolutionary processes, that it was pretty important in constituting social life as actually experienced, and that removing any of these big pieces might well have drastically altered that experience. ${ }^{85}$

The disengaged have added persuasively to the critiques of functionalism, at least in the area of lawyer's law. But those of us whom they have failed to convince of law's total irrelevance to social life have to look elsewhere for our theory. One obvious place to look for

84. See Epstein, supra note 78. Individual statutes also may not have mattered. though Epstein, curiously, distinguishes these. See id. at 1718-20.

85. Even more methodologically questionable than the fragmentation of legal causes and effects into isolated events-hardly of course a problem confined to the disengaged alone-is the positivist attitude that encourages such fragmentation: the assumption that the only kinds of statements about reality that are worth coming up with are empirically falsifiable statements about the probabilities under varying specified conditions that certain "legal behaviors" will elicit "social behaviors" (or vice-versa) in response. Sometimes this atritude deepens into the absurd claim that whatever you can't make such a statement about must not be there at all! This attitude is not confined to the disengaged; indeed, it has recently been voiced within CLS itself, in an exceptionaliy interesting piece by Alan Hyde that questions the utility of the concept of "legitimation" in legal sociology, essentially on the ground that the theory that people obey laws because they think them legitimate lacks convincing empirical support. See Hyde, The Concept of Legitimation in the Sociology of Laiu, 1983 Wis. L. REv: 379.

This isn't the place to attempt a comprehensive critique of Hyde's careful and detailed argument. But I would like to relate the following story, adapted from John Womack's great history of the Mexican Revolution: The Revolution started because sugar planters began to expand their landholdings in order to rationalize the practice of commercial agriculture. They used force to expel peasants from their lands, but took care to back up every expulsion with land registration legislation, recording acts. and condemnation proceedings, all ratified by local courts. The villagers, for their part. saw themselves as defending legal title to their lands. The chief of the Morelos pueblo passed on to his successor, Emiliano Zapata, the pueblo's most precious possession, a packet of title documents. Zapata and his followers joined the revolution because they could not get "justice" (true law) through existing forms of law. They fought to establish national and local governments that would do justice Throughout the struggle the villagers would surrender positions held by force in return for legal guarantees (winich if given were always betrayed). See J. WOMACK. ZAPATA AND THE MEXICAN REVOLLTION 44, 52-66. 371-82 (1968).

The planters and their political allies would not move except under the forms of law-to reassure foreign countries, the potentially hostile middle class, and (as much as anyone else) themselves that the rights of property were on their side. The pueblo rose in revoit because their rights of property had been violated. I really don't know whether the concept of "legitimation," admittedly vague, overused, stretched to fit far too many different purposes, is the best concept to use in explaining why legal forms mattered so much to these people. but I can't help thinking that some kindred notion must be. 
a theory of the social relevance of law is at theories of the law as legitimating ideology.

\section{Law as (legitimating) ideology.}

Like the theory that law serves the interest of dominant groups, this one has come to be associated with the left, but again there's no necessary connection. Mainstream liberal functionalism has its own, Durkheimian version of the legitimating role of law: Legal norms are primary expressions of and means of reproducing the "shared values" that function as the integrating glue in liberal societies, orienting everyone's highly differentiated tasks towards a set of common social purposes. ${ }^{86}$ But concededly it has been the left-wing theories, theories that have emerged to deal with the difficulties posed by the "autonomy" problem for any account of law as the direct instrument of class oppression, that have attracted the most attention. Let me, for convenience's sake, try to arrange some of these theories on a spectrum, starting with those closest to straight instrumental theories, and ending with those emphasizing the most diffuse and indirect ways in which law makes up the elements of a culture:

(1) "All law is pig law dressed up in judges' robes." That is, law is a means for organizing the ruling class and for coercing, cheating, and disorganizing the working class. Thus, law allows capital freely to collectivize but sets limits on labor combinations; it allows "capital strikes" (disinvestment) but restricts labor strikes; it confirms capitalist control over the organization of work; it criminalizes "vagrancy" as a means of keeping docile the urban unemployed; and it provides that employment is "at will" so that the unorganized work force has no job security.

(2) "The ruling class induces consent and demobilizes opposition by masking its rule in widely shared utopian norms and fair procedures, which it then distorts to its own purposes." For example, the classical bourgeois legal norms of "private property," "free contract," "free speech," and "due process" express universal longings for security, privacy, autonomy, free choice about what to buy and sell and whom to work for, the right to speak one's mind freely, and the universal desire for protection against arbitrary coercion. But in a class society these supposedly universal norms are deployed for the benefit of a particular class. Private property, free contract, (complex and expensive) due process, (well-heeled-and-organized-interest-group-re-

86. See, e.g., T. Parsons, The Structure of Social Action (2d ed. 1949). 
sponsive) democratic procedures, and even (expensive-and-technology-dependent) free speech operate de facto to reinforce the advantages of wealth and power. The victims of these outcomes feel powerless to complain because the outcomes seern to have been produced by legitimate rules and procedures.

(3) "The ruling class confirms its rule by actually making good on enough of its utopian promises to convince potential opposition that the system is tolerably fair and capable of improvement, even with all its faults." This proposition is essentially Machiavellian. The ruling class periodically sets up demonstrations to convince people that it really does rule in the universal interest. ${ }^{87}$

(4) "The ruling class itself is taken in by legal ideology; it believes that it's acting justly when it acts according to law, that everyone is getting approximately the best possible deal, and that change would make everyone worse off." This formulation is getting closer to the meaning of ideology in classical social theory: a partial vision of the world that appears to its proponents as well as to its victims as a universal vision. (In fact, in the case of the ideology of the "rule of law," middle-class people are rather more sold on it than working or lower-class people.)

(5) "Law isn't just an instrument of class domination, it's an arena of class struggle." The content of legal rules and practices is ideologically tilted in favor of class rule (or, more generally, the reproduction of current modes of hierarchical domination, class-based

87. Some scholars who equate all left-wing legal thought and even "Marxism" with this ruling-class-conspiracy notion complain about how unfair it is: The ruling class is damned if it screws the underclass and damned again if it treats it justly; what evidence would show that the ruling class wasn't oppressive? See, e.g., Langbein, Albion's Fatal Flawes, PAST \& PRESENT, Feb. 1983, at 96, 114-15. I would respond to this criticism in several ways: First, historical ruling classes have often behaved exactly as Machiavelli said they should. That is, they have self-consciously reformed legal practices, making them more impartial and equitable, for the precise purpose of staving off popular risings or of stealing the wind from political opponents. The strategy is surely part of the prudential repertoire of any ruler, although it may not always figure in the motivations behind the setting up of any particular regime of apparently impartial justice. Much more important, the complaint simply misses the point of the radical's analysis of legal practices, which is usually meant not to criticize the rulers for ruling nicely or to impugn their motives, but to help explain how a ruling class (especially a small one in a large population, or one without a large standing army or police force) maintains its rule." "By force and fraud," is always a part of the radical's answer, but especially in advanced Western societies where the direct threat of force is uncommon, the usual answer is. "by consent (however grudgingly it may sometimes be given)." How does the ruling class induce consent? By persuading people that they are getting, if not a good deal, at least the best one they are likely to get, or perhaps the best one they are likely to get relatively easily (because anything better would require much struggle, disruption, and above all the risk of catastrophic failure). 
or otherwise), but ruling classes don't have everything their own way when it comes to specifying that content. The concessions that cause legal systems to respond to the interests and ideal aspirations of the dominated result from bargains struck after hard struggle. The norms embodied in legal rules therefore are always double-edged: The underdogs who have won them can also be coopted by them; the overdogs who concede them in order to coopt are always vulnerable to being undermined by their radical potential. ${ }^{88}$

(6) "The discourse of law-its categories, arguments, reasoning modes, rhetorical tropes, and procedural rituals-fits into a complex of discursive practices that together structure how people perceive and that therefore act to reproduce or to try to change people's social reality." Because this assertion goes well beyond partial critique, and is one of the core views of many of the Critics, I'll postpone elaboration of it until the next section.

\section{Law as Symbols and Rituals.}

This is a catch-all heading for those writers who see much of what goes on in the legal system as theatrical or religious public spectacles and story-telling sessions that infuse ordinary social life with dramatic meanings and messages: the triumph of Virtue over Corruption, the marking off of a "sacred" sphere of ideals from the "profane" world of fallen self-interest, the purification of society of polluting deviance, the proclamations that most economic transactions are fair and decent implicit in the stigmatizing of a few deals as exceptionally rotten, the instruction that life is a game to be played according to rules, and the trappings that tell you that authority is authority.

I'm not sure why cultural anthropology of this kind, which seems to me to be potentially one of the most exciting and fruitful sources of new insights about law, is so undeveloped in our scholarship, especially since of what little there is, so much is marvelous work. ${ }^{89}$

88. An important strand of Critical historical writing descends from this set of insights. See, e.g., E. Fox-Genovese \& E. Genovese, Frutts of Merchant Capital 337-87 (1983): E.P. ThOMPSON, WhiGs AND HUNTERs 258-69 (1975).

89. See, e.g. T. ARNOLD, The Folklore of CAPITAlisM 185-88 (1935)(corporate reorganization rituals); M. FouCAULT, Discipline AND PUNISH (1977) (dramaturgy of executions): L. Friedman, The Roots of Justice: Crime and Punishment in Alameda COUNTY, CALIFORNIA, 1870-1910, at 150-95 (1981) (felony processes making hapless vagrants into cardboard villains); E. KANTOROWICZ, THE KING'S 'TwO BODIEs (1957) (medieval kingship); Hay, supra note 78, at 17-18 (terror-theatre of criminal assizes); Leff, Lau' and, 87 YALE L.J. 989 (1978) (litigation rituals). 
Doubtless part of the reason is our scholarship's occasionally constricted positivist criteria for its rare excursions into social description, which sometimes suppose that whatever "effects" of law you can't measure precisely must not be there at all; the rest is perhaps simply that this sort of work is very hard to do.

\section{F. Variation \#6-Drawing upon Different Story-Lines}

I have argued that the dominant vision of the meaning of modern history is an optimistic liberal vision. ${ }^{90}$ Its principal story-line is one of the gradual recession of error before the advance of commerce, liberty, and science-an advance modestly but invaluably assisted by ever more efficiently adaptive technologies of law. There have been failures and setbacks, and work remains to be done; but we have triumphed over the major obstacles, and the remaining work is remedial reform of the details. To be sure, opposing schools within optimistic liberalism have developed somewhat conflicting stories: One sees the late nineteenth-century common law as the summit of legal enlightenment and the regulatory welfare state as a (presumably temporary) slide into Serfdom and Inefficiency; the other sees the late nineteenth-century as a colossally misguided aberration and the regulatory welfare state not only as a useful corrective but as a continuation of the true American tradition of positive state interventions in the interest of the commonwealth.

Such sharply conflicting views even within mainstream functionalism had already shattered the tranquil complacency possible only to those in possession of uncontested mythic-historical ground, but this discord was nothing compared to the cries of distress that followed the appearance of Morton Horwitz's The Transformation of American Law. ${ }^{91}$ As an event in the history of American legal/intellectual culture, this book is most interesting for its substitution of some of the major pessimistic story-lines available in our culture for the optimistic ones of the dominant vision: ${ }^{92}$ first, the story of the dark side of capi-

90. The vision, as it has approached gur own time, has modulated its optimism into a kind of grimly resigned complacency, which finds its tragic consciousness of flawed and futile human capacities an inexhaustible stock of reasons why it would be futile to try to imagine any better forms of social life than those that we happen to be accustomed to.

91. M. HORnitz, supra note 56. For reviews explicitly Critical of the book for its pessimism (though coming to diverse overall judgments), see McClain, Legal Change and Class Interests: A Review Essay on Morton Horwitz's The Transformation of American Law, 68 Calif. L. REV. 382 (1980); Gilmore, Book Review, 86 YALE L.J. 788 (1977), Reid, Book Review, 55 TEX. L. Rev: 1307 (1977); Teachout, Book Review, 53 N.Y.U. L. REV. 241 (1978).

92. To my mind, however, the permanent importance of this book to scholarship lies in its subtlety and richness as a history of legal ideology - an aspect of Horwitz's argument that 
talist development-the destruction of communal bonds and meaningful faiths, the wrenching apart of families, the abolition of honorable crafts, the routinization of work, the displacement of norms of equitable dealing by an ethic of self-seeking as the highest good; ${ }^{93}$ second, the story of the declension from the Founders' vision of Republicanism as the participation of independent citizens in civic association for the public good to a business society of profit-maximizing privatistic individuals; ${ }^{94}$ third, the Populist story of the betrayal of the Revolutionary promise of democracy by plutocrats who have, since the first Constitutional Convention, managed to wrest the machinery of law and government away from the People and press it into the service of the wealthy and powerful. ${ }^{95}$

I attribute a good deal of the horror in the Critical reaction to Horwitz, not to mention the absurd label of "Marxism," to his violating so many of the traditional canons of story-telling all at once. After all, these story lines had been expressed previously by other writers. ${ }^{96}$ It was all right for "social policy" to be instrumental to economic purposes so long as these purposes were benign (industrialization, economic growth, the needs of development) and so long as one was mostly talking about legislatures. Horwitz, however, made

the many hostile reviewers who have pointed out its very real vulnerabilities as social and economic history have chosen to ignore almost completely.

93. For an excellent survey and analysis of this deviant story-line, see Hirschman, Rival Interpretations of Market Society: Civilizing, Destructive, or Feeble?, 20 J. ECON. LrT. 1463 (1982).

94. For a discussion of the persistence of the "republican" themes of the establishment of civic virtue and its corruption in American life, see, e.g., Ross, The Liberal Tradition Revisited and the Republican Tradition addressed, in New Directions in AMERICAN INTELlectual HisTORY 116 (J. Higham \& P. Conkin eds. 1979).

95. The cornerstone work in this tradition is C. BEARD, supra note 77.

96. All of these are staple crops of mainstream Atlantic culture-so much so that I'm staggered by hearing their use in Horwitz' book so constantly called "Marxist." For God's sake, at any bar dinner you can listen to the most conservative lawyers talking about how the fellowship of the bar (community), sense of professionalism (craft ethic), and devotion to the public good (republicanism) have declined as the practice of law has become a business devoted to making money. Other legal historians had sounded these themes as well. Hurst told how the capitalist ethic had destroyed public-regarding values as well as the Wisconsin timberland in the mid-nineteenth century. See W. Hurst, Law and ECONOMIC Growth (1964). Nelson and Reid lamented the sinking of the idea of law as expressive of communal morality in the atomistic individualism of a commercializing nation. See W. NELSON, AMERICanization of the Common Law (1975); J. Reid, In a Defiant Stance (1977); see also Hartog, Distancing Oneself from the Eighteenth Century: A Commentary on Changing Pictures of American Legal Hislory, in Law in the American Revolution and the Revoliction in Laiv 229 (H. Hartog ed. 1981). Scheiber showed how early corporate enterprise had manipulated law to expropriate traditional rights as it marched onwards. See Scheiber, Property Law, Exproprialion, and Resource Allocation by Govemment, $33 \mathrm{~J}$. ECON. HIST. 232 (1973). But somehow none of them ever provoked anything like the hostility that Horwitz did. 
over the purposes into capital accumulation through expropriation and protection of profits from redistribution. He also implicated elite lawyers and judges, and with them the common law tradition of which they were the curators, as among the ringleaders of this dubious business. It was even all right (in the Realist tradition) to charge common law judges with class-biased rulemaking, so long as one safely limited the indictment to the ephemeral craziness of late nineteenth-century Formalism. Horwitz carried the charge back to the early nineteenth century, the period that common lawyers had previously celebrated as their heroically "formative" era. I don't deny, and neither at this date would Horwitz himself, that there are problems with his thesis, and that some of the specific criticisms of his evidence and conclusions are sound. But it's hard to account for the volume and intensity of the adverse reactions without understanding why the thesis should have touched so many nerves.

The reason all this matters is that the new availability of major deviant story-lines about the main action in modern social/legal history has the effect.of relativizing the old story-lines, of making them look not like uncontroversial assumptions but like what they are: some among many possible interpretive frameworks in which to stick historical evidence.

\section{G. Variation \# 7-Historicize Consciousness}

The final twist on the dominant tradition that I'd like to mention here, one that ends up playing a central role in Critical thought, is simply the "Kuhnian"97 or "Collingwoodian"98 idea that the most basic ways in which people conceive of the natural and social universes in which they live, the most elementary categories that people use to organize everyday life, are culturally and historically contingent; that is, they are specific to given places and times. Pure functionalism, as we've seen, objectifies both social needs and adaptive responses, claiming that these are universal categories of real life: hypothetically, you can always tell, if you get enough data on a society, what its needs are and whether its social forms efficiently meet them. The historicist perspective, on the other hand, teaches that even the conceptual language in which the functionalist advances her claim of universal needs and adaptations is a time-and-culture-bound language with a history-not a gentle progressive history in which su-

97. See T. Kuhn, The Structure of Scientific Revolutions (2d ed. 1970).

98. See R. Collingwood. The Idea of History (1946). 
perstition gradually gives way to science, but a history with revolutions and disruptions in it.

There are two basic ways of pursuing the historicist approach. One is simply to write the history of our own modes of thought, to try to identify when our categories for organizing how we speak about law solidified into something like their present shape. When, for example, did we separate a private realm of "market" activity from a public realm of "state" activity and come to think of the latter as "intervening" in the former? When does the term "regulation" begin to be used in its modern sense? When did tort separate from contract, "corporation" come to mean mostly "private business enterprise," and "efficiency" achieve its present significance for antitrust lawyers? When did lawyers start speaking of the the need to "balance" a multiplicity of "interests" in order to decide hard cases?"

The other technique is the reconstruction of historical or crosscultural modes of thought in such detail as to illustrate (a) that other societies have not shared the ways of thinking that we believe to be essential and obvious (they just don't have a counterpart conception to our idea of a "market" or of a "free individual," they don't think a "corporation" is legally any different from a family or a city, and either they don't distinguish between a "public" and a "private" realm or they mean something completely different by the distinction), and (b) that these views were completely plausible for the people who held them. ${ }^{100}$ Such work can have a real political edge to it, as when the historian takes a set of ruling ideological conceptions that his own time condemns as cruel or mistaken-legal rationalizations of slavery, for instance, or the due process Formalism of the Lochner era-enters into their world with (provisional) sympathy, and then shows how much sense those conceptions make on their

44. Perhaps the closesi analogues to the histories of legal consciousness now being written br many of the Critical legal historians are the histories of ecunomic thought which study the historical emergence of its fundamentals. such as the grounding of social action in individual subjects rationally pursuing self-interest through exchange. See, e.g. J. APpLEB\}, E(r)-

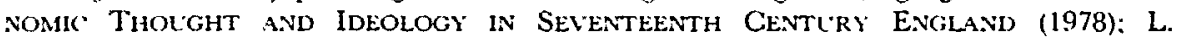
DLMONT, From MaNdel ILle to MaRX (1977); A. Hirschman, supra note 12: K. POlanit. THE GREAT TR.ANSFORMation (1944).

100 Some of the very best legal/historical writing does exactly this: Maitland's or McIlwain's reconstruction of medieval world-views: Hurst's description of nineteenth-century American "bastard pragmatism"; Gordon Wood's recreation of the conceptual world of the Constitution-writers. W. HLRST, supra note 96, at 206: C. MCIlWAIN, THE HigiH COL RT (SF Parlianent avd its Supremacy (1910); F. Pollock \& F. Maitland, supra note 64: G. WOOD, supra note 77. 
own terms. ${ }^{101}$ The ways in which well-meaning gentlemen justified their social order - the social order that had so well situated themas just and efficient may look uncomfortably familiar. But the leading edge of historicism cuts deeper still: it tells us that the difficulties we have in imagining forms of social life different from and better than those we are accustomed to may be due to the limits on our conceptions of reality rather than to limits inherent in reality itself. After all, perfectly smart and forward-looking Americans of about a century ago habitually believed such things as that social order and economic prosperity depended absolutely on the maintenance of permanent class divisions or slavery; that it was absurd utopianism to suppose that blacks and whites could ever associate on terms of social intimacy or equality (or if they did, the results would be biological degradation of the species); that the physical constitution of women unfitted them for attendance at colleges, that unemployment insurance would take all the discipline and will to work out of the labor force; and that judicial failure to enforce harsh bargains to their rigorously formal letter would bring on the imminent collapse of capitalism.

Such historicism is not, in its weaker versions, actually incompatible with functionalism. One could continue to suppose that universal processes generate needs for ideally adaptive responses while conceding that both needs and responses will be perceived at different times and places through different-colored, and more-or-less distorting, conceptual lenses and filters. The strong position, on the whole that adopted by Critical writers, is that both needs and responses, and indeed the idea of needs-and-responses itself, must be seen as the cultural products of contingent modes of thought.

\section{Generalizing and Deepening the Critiques: Critical LEGAL HISTORIES}

Having at last completed the catalogue of variations, let me restate in summary form those that have done the most to inform the varieties of Critical historiography:

1. The conditions of social life and the course of historical development are radically underdetermined, or at least not determined by any uniform evolutionary path.

101. See, e.g., E. Gerotese, The WORLd the SLAveholders Made 114-244 (1969): M. TLShivet. The American Law OF Slalery, 1810-1860 (1981): Kennedy. Tou'atd an Historical Linderstanding of Legal Consciousness: The Case of Classical Legal Thought in Antenca, 1850-1940, in 3 RESEARCH L. \& Soc. 3 (1980). 
2. The causal relations between changes in legal and social forms are likewise radically underdetermined: Comparable social conditions (both within the same and across different societies) have generated contrary legal responses, and comparable legal forms have produced contrary social effects.

3. If a society's law can't be understood as an objective response to objective historical processes, neither can it be understood as a neutral technology adapted to the needs of that particular society. Legal forms and practices are political products that arise from the struggles of conflicting social groups that possess very disparate resources of wealth, power, status, knowledge, access to armed force, and organizational capability.

4. Although they are the product of political conflict, legal forms and practices don't shift with every realignment of the balance of political forces. They tend to become embedded in "relatively autonomous" structures that transcend and, to some extent, help to shape the content of the immediate self-interest of social groups.

5. This relative autonomy means that they can't be explained completely by reference to external political/social/economic factors. To some extent they are independent variables in social experience and therefore they require study elaborating their peculiar internal structures with the aim of finding out how those structures feed back upon social life. Given what so often appears to be the indeterminacy of instrumental effects, a promising approach for such study may be to treat legal forms as ideologies and rituals whose "effects"effects that include people's ways of sorting out social experience, giving it meaning, grading it as natural, just, and necessary or as contrived, unjust and subject to alteration-are in the realm of consciousness.

6. Our accustomed ways of thinking about law and history are as culturally and historically contingent as "society" and "law" themselves. Though we can never completely escape from the limitations of our environment, we can to some extent protect against the risk of simply projecting our parochial categories onto the past with a self-conscious effort to relativize our own consciousness, by trying to write the story of its formative context and development and by trying to reconstruct as faithfully as possible the different mentalities of past societies before translating them into our own.

7. It will also help us to relativize our understanding of the past's relation to the present if we see that our conventional views of that relation are mediated by familiar narrative story-lines, that are 
so deeply entrenched in our consciousness that we are often unaware of their rule over our conception of reality. These story-lines, like other mentalities, have a history filled with ideological purposes, and there always exist-and so we always may draw upon-competing stories that impress the same historical experience with radically divergent meanings.

Taken en bloc rather than separately, this set of partial critiques adds up to a position that most people who see themselves as doing Critical legal historiography would probably accept. ${ }^{102}$ Many, though by no means all, ${ }^{103}$ would want to push the critique still further.

\section{A. Blurring the "Law/Society" Distinction}

You might think that after the ravages of partial critique there would not be much left of the dominant tradition. But there is. Its skeletal frame, its division of the world into social and legal spheres, tends to endure. Thus, even the more severe of the partial critics continue to assume-although conceding that all over the landscape of social life we can see the imprints, some deep and others almost imperceptible, of feedback reactions from the "autonomous" outputs of the legal system-that at bottom the really basic terms of commu-

102. I want to be clear that I am not making the absurd claim that particular people affiliated with the Critical Legal Studies movement have originated these critiques. On the contrary, those critiques are virtually all of long historical standing, to be found in Hegel or Marx if not before; incorporated into the normal working assumptions of many social theorists (e.g.; Weber, Durkheim, Gramsci, Foucault, Giddens, Offe); historians of political and economic thought (e.g., Maitland, McIlwain, Ernst Kantorowicz, Pocock, Quentin Skinner, Karl Polanyi. Hirschman); social historians (e.g. Bloch, Genovese, E.P. Thompson, M. I. Finley); virtually any modern intellectual historian; philosophers of science (e.g. Kuhn); and cultural anthropologists (e.g., Geertz, Turner, Sahlins); as well as many legal intellectuals, specifically among Legal Realists, sociologists, and historians. (This is my own, doubtless idiosyncratic list: others might well put together a different one.)

What some CLS people have done, I think, is (a) to combine these critiques in an interesting way; (b) to attempt to go somewhat beyond them, as specified in the next section; and (c) to apply the results to the historiography of American legal doctrine and institutions. (Even in these respects their work has been anticipated by others: I re-read recently a book published nearly 40 years ago that seemed to me to fit most of the characteristics of what I'm here calling "Critical" legal historiography: Louis Hartz's Economic Policy and Democratic Thought: Pennsylvania, 1776-1860 (1948).) Critical work may thus perhaps best be described as "distinctive" rather than "original," for surely it was only a matter of time before approaches already so well developed in other fields of learning would be applied to law. I mention this because scholars hostile to CLS work so often say, "Well, that's all old hat: there's nothing original about that," using (as I see it) the accusation of unoriginality as a reason for not engaging with the substance of the work. Let's all simply stipulate that it's not "original," that it's within a "school" or "tradition," and leave it at that.

103. See for example the debates summarized at notes 127-40 infra. 
nity life are set by conditions and relations we can, and should, describe independently of law: family ties, personal affections, power struggles, technology, consumption preferences, association in interest groups, and the organization of production. These conditions and relations-the realm of "material life" in some formulations; of "basic needs" of all societies or of particular evolutionary stages in evolutionary functionalism; of "the forces of production" in some Marxisms; of the "interests" of individuals or groups in liberal pluralist theory; and finally of the "preferences" of self-constituting individual subjects in the ultimate reduction of classical and neoclassical economics-comprise the "real world" which law may serve or disserve or even partially twist out of shape but to which law is ancillary. The fundamental operations of this world originate before law and go forward independently of it; they fashion in general outline (if not in tiny detail) the agendas and limits of legal systems and are beyond the power of law to alter.

Yet, in practice, it is just about impossible to describe any set of "basic" social practices without describing the legal relations among the people involved-legal relations that don't simply condition how the people relate to each other but to an important extent define the constitutive terms of the relationship, relations such as lord and peasant, master and slave, employer and employee, ratepayer and utility, and taxpayer and municipality. For instance, among the first words one might use to identify the various people in an office would likely be words connoting legal status: "That's the owner over there." "She's a partner; he's a senior associate; that means an associate with tenure." "That's a contractor who's come in to do repairs." "That's a temp they sent over from Manpower." This seems an obvious point, but if it's correct how can one square it with the standard view of law as peripheral to "real" social relations? Could one, for example, seriously assert that "the law of slavery has tended to play only a marginal role in the administration of slave societies"? Slavery is a legal relationship: It is precisely the slave's bundle of jural rights (or rather lack of them) and duties vis-à-vis others (he can't leave, he can't inherit, he has restricted rights of ownership, he can't insist on his family being together as a unit, etc.) that makes him a slave. ${ }^{104}$

104. See Finley, The Servile Statuses of Ancient Greece, in ECONOMY AND SOCIETY IN ANCIENT GREeCE, 133, 134-35, 148-49 (B. Shaw \& R. Saller eds. 1981) (using the "juristic" method, accompanied by proper cautions about its limits, to analyze the spectrum of servile statuses in the ancient world). I see no reason to change this conclusion after reading Orlando Patterson's important new study attacking strictly "legal" accounts of the master-slave relation. See O. Patterson, Slavery and Social Death: A Comparative Study 1-62 
Change the bundle significantly and you have to call him something else. And how could one say something like "medieval law bolstered (or undermined) the structure of feudal society"? Again, a particular (though concededly in this case very hazily defined) set of legal relations composes what we tend to call feudal society. If those relations change (commutation of in-kind service to money rents, ousting of seignorial jurisdiction to punish offenses, etc.) we speak not simply of changes in "the legal rules regulating feudal institutions," but of the decline of feudalism itself.

I would guess that the notion of the fundamentally constitutive character of legal relations in social life is probably a lot easier to understand when made about slave or feudal societies than about liberal societies. After all, in liberal societies, differences of legal status are not supposed to define social relationships, but merely to channel and facilitate them. In theory, one can, in a liberal society, choose one's legal status to suit one's underlying, material, functional, real purposes; with "freedom of contract," one even gets to create that status within the limits set by public law. But a whole generation of Realists taught us to see that a regime of free contract delegates to those who contract legal powers, subject to a host of important legal exceptions, to coerce performance according to the contract; ${ }^{105}$ and the establishment of private property gives the proprietor a set of legal powers, again subject to important legal limitations, to dictate to others the terms of access to his property: ${ }^{106}$ and the chartering of a corporation entitles the managerial Few to make binding decisions affecting the lives and fortunes of the laboring and shareholding Many. ${ }^{107}$ These bundles of rights and powers, diminished by exceptions and limitations, with which members of liberal societies are endowed, are Critical determinants of the terms of their relations with one another. For instance, it usually matters a lot in an employment relationship whether or not Employee is or is not

(1932). For one thing, neither I nor any of the Critics would ever describe a set of social relations in excluswely. legal terms. For another, Patterson's attack is really only on a particularly misleading legal account of slavery as "property rights in human beings"; as he truly says, slavery is only a special case. a peculiar bundle. of such rights. The real question for him is how such a set of legal relations is created, which he argues is by a process of "symbolic appropriation" resulting in the slave's "social death." For the consistency of this approach with that of the Critics. see text accompanying notes 115-24 infra.

105. See. e.g., Hohfeld, Findanental Legal Conceptions (1923).

106. See, e.g. Cohen, Properly and Saiereignty, 13 CORNell L.Q. 8 (1927); Hale, Coercion and Distribution in a Supposedly Non-Coercive State, 38 POL. SCr. Q. 470 (1923).

107. Jacobson, The Privale Use of Public Authority, Sovereignty and Assaciations in the Common Lau, 29 BLFFalo L. REY. 599 (1981). 
employed at will, a major stockholder of the business, an illegal immigrant, married to Employer, protected against being fired for trying to organize other employees, and so forth. In each case, a different complex of background legal entitlements factors into the power relations between the parties. Of course, nobody is going to claim that law explains more than a fraction of the power differences between these people. The employee may be the only person who understands the filing system, or be irresistibly attractive or physically intimidating, or just have been there for ages, or have lots of alternatives in the market (though of course that "market" itself is importantly structured by the legal regulations of what may be owned and traded in it, subject to limitations, and by the property entitlements of all the traders in it). ${ }^{108} \mathrm{It}$ is, of course, possible to imagine, as for example G. A. Cohen has done in his extremely ingenious attempt to demonstrate that one can describe a "material" core of social relations without any "law" in them at all, ${ }^{109}$ a Hobbesian power balance of force that is destabilized every time somebody sharpens a stick or lifts a weight. But in actual historical societies, the law governing social relations-even when never invoked, alluded to, or even consciously much thought about-has been such a key element in the constitution of productive relations that it is difficult to see the value (aside from vindicating a wholly abstract commitment to "materialist" world views) of trying of describe those relations apart from law. Power is a function of one's ability to form and coordinate stable alliances with others that will survive setbacks and the temptations of defection to satisfy opportunistic interests. Such organization and coordination are bound to involve something legal. Indeed, one is likely to find the conditions of the Hobbesian state of war precisely in those instances where law has explicitly or by

108. To give another example, assume two people are having an argument in a car. One says, "Get out of ny car." The other says, "It's not your car, it's the company's car. I have as much right to be here as you do." The first: "I'm driving today, so as far as you're concerned it's my car: and I want you to get out." This is of course a fairly complex. if utterly commonplace legal argument-unusual if at all only in that the claims and counterclaims are very explicit instead of being just silent background assumptions. Of course, factors other than legal relations may be involved. One of these guys may be a lot bigger than the other or have a long-run stake in the other's amiability or good opinion. But the law of the situation is a potentially critical factor in its resolution.

109. Sie G. Cohex, Karl Marx's Theory of History: A DerenCe 216-48 (1978). The book as a whole is a brilliant attempt to rehabilitate an orthodox-Marxist version of functionalism, in which, as in the dominant vision, law is one of the ideological superstructures called into being by the requirements of the material forces of production, which then reacts upon and mingles with those material forces. For a particularly useful (and to me, convincing) response to Cohen, see H. COLLINS, MARXISM AND LAW 81-85 (1982). 
silence established a combat zone in which people are endowed with (in Hohfeldian terms) privileges to inflict harm upon one another and are denied any legal means of restricting that harm (as when the legal regime says a wife can't be raped or that contracts between husband and wife are not enforceable). Clearly (as Cohen for example points out ${ }^{110}$, people can struggle to improve their position vis-àvis others by changing the rules that define their entitlements, but that doesn't alter the fact that the bundle of legal endowments they start out with positions them for the struggle, and may make all the difference as to whether they win, lose, or get a good compromise deal. The new deal, when sufficiently stabilized in practice, will simply be the new legal constitution of their relationship.

More prosaically, the "interests" in the instrumental account that make demands upon the legal system are not self-constituting prelegal entities. They owe important aspects of their identities, traits, organizational forms, and sometimes their very existence to their legal constitution. For example, "taxpayers" are partially families, partnerships, or individuals, because of the legal definition of these units; "New England gas consumers" pressing the Congress for relief from high prices are partially a "regional interest" because of the legal form of territorial representation; "Communists" are not an interest represented as such in labor unions because of legal excommunication; whereas the true identity of the "corporate client" to whom a corporation's lawyer owes her undivided loyalty is an unsolved mystery, because of conflicts in legal theory. For the most part, the legal creation of "interests" and the selection of their representatives proceed too quietly for notice-save on those occasions where formal choice must be made, as in deciding whether the "Sierra Club" may represent people who care about the environment in class actions or administrative proceedings. ${ }^{11}$

Understanding the constitutive role of law in social relationships is often crucial not only in characterizing societies but in accounting for major social change. Robert Brenner's remarkable work on preindustrial Europe, ${ }^{12}$ for instance, identifies two general patterns of social adjustment to the population declines of the late Middle Ages: a (typically) Western pattern in which the labor shortage re-

110. G. COHEN, supra note 109, at 216-48.

111. See, e.g. J. VINING, LEGAL IDENTITY (1978); Katz, Siudtes in Boundary Thion: Three Essays in Adjudication and Politucs, 28 BtFralo L. REV. 383 (1979); Yeazell. From Group Latigation to Class Action Part II: Interest. Class and Representation, 27 C C.C.L.A. L. REv. 1067 (1980).

112. Brenner. Agrarian Class Structure and Economic Development in Pre-Industrial Europi. PAST \& PRESENT. Feb. 1976, at 30. 
sulted in more favorable labor terms for the peasantry, and a (typically) Eastern pattern in which the same shortage brought about an intensification of serfdom, a tightening of the lords' control over their serfs. Brenner's (richly detailed and here much simplified) explanation for this dichotomy is that the landlords' ability to tighten control instead of having to grant concessions depended critically upon the balance of class power that had come to prevail in their particular society. A central component of this power balance was the set of legal relationships that had been established between the classes. Where peasant communities, were strongly organized, they had, over the centuries, managed to wring concessions from their lords, which had been institutionalized as law. Thus institutionalized as rights, these concessions could not be withdrawn without provoking massive resistance. ${ }^{113}$ Brenner goes on to argue that where (as in France and parts of western Germany) these customary rights of peasant proprietorship persisted through the early modern period they did so because centralizing states helped to secure these rights against the lords and thus retarded the process of capitalist consolidation of landholdings. In England, by contrast, where such rights had been eroded for a complex of reasons, small proprietors were unable to resist eviction.

Maybe the point that law and society are inextricably mixed seems hard for legal writers to grasp because they sometimes restrict their view of what law is to a bunch of discrete events that occur within certain specialized state agencies (in the most restrictive view, the courts alone) and therefore assume that the only question for a social history of law is the relation between the output of these agencies and social change. But if that output is all there is to law, how on earth are we going to characterize all the innumerable rights, duties, privileges, and immunities that people commonly recognize and enforce without officials anywhere nearby? Slavery, for instance, may well make its first appearance in the temporary emergency practices of a settlement, harden over the next few planting seasons into invariable custom, and, decades later, when the localities decide they want the help of centralized enforcement authority, become the subject of legislation in slave codes. When should a sociologically

113. Whoever objects at this point that the "law" involved in this description is only epiphenomenal to the "social fact" of "organization" will have to try to find some way to describe that organization without mentioning the rules whose maintenance was its rason d'elre or the institutional forms in which its tasks were carried out-not to mention "Fight to Protect Your Rights!" as a means of organization itself. 
minded historian (as opposed, for example, to a legal-positivist jurisprudent) start to speak of the emergence in this society of the legal institutions of slavery? At any point, I should think, when she finds the ordinary practices and discourses of that society assuming or appealing to the collectively shared and maintained notions of right and obligation that support that institution, the moment when power becomes institutionalized as "right." Thus, the social/legal historian who began her account of slave law in these settlements with the codifications would rightly be accused of leaving out the most important part of the story. ${ }^{114}$ Furthermore, even if the historian refused to recognize custom as law until it was ratified by some official agency, she won't get very far towards understanding the role of law in social change if she looks only for the immediate social effects of marginal changes in discrete enactments and ignores the whole invisible background network of rules (like the basic law of property) that are silently incorporated into people's lives.

Again, since it all seems so incredibly obvious once it's said, what explains the persistent view of law's marginality in social life? Partly, it comes from the view of generations of disillusioned reformersliberal reformers mostly, I suspect-who have come to doubt . whether more than marginal social change can be achieved through deliberate promotion by those in control of the mechanisms of the liberal state. But this proposition is not really about the limits of law; it is about the limits of selective types of attempts to reorient, usually from the top down, selective formal institutions. Most legal change takes place all through civil society, in thousands of small interactions usually with no official visibly present at all. It's strange, in a way, that the Realist and Law-and-Society scholars, who taught us to see the law "in action" as well as the law "on the books," should so often be the very same people who revert to restrictive Formalist views of law when they stress, in Pound's words, "the limits of effective legal action." There is a real disjunction here between their sociological analysis of the law constituting the status quo as dynamic, informal, and political, and their programmatic analysis of the law needed to bring about change as static, formal, and bureaucratic.

The view that law is marginal in social life probably also registers

114. Actual historical societies have conveniently simplified her task in some cases by adopting prefabricated bundles of officially-legal relations. The way slavery came to the Virginia settlements, for instance, was by importation of blacks who were already enslaved somewhere else. W. JORDAN, WHITE OVER BLACK 71-82 (1968); E. MORGAN, supra note 60, at 295-337. The story nicely illustrates the point that when people go about putting together their "material" economies, they use the "ideal" building blocks of legal relations. 
an overreaction to the preceding generation of Formalists, who often behaved as if once you described the legal form of an institution or practice, you had described the whole thing. A "corporation" or a "city" appeared as nothing more than a shell of legal rights and powers. The Realist successors to these Formalists yearned to break through the formal shell to (as they often expressed it) the "living" reality beneath it: the "realities" of trade practices, power politics, emotional ties, "behavior," and, of course, social needs. But there is no way to detach essences from their forms: The law (in the catholic sense that I've been using) was all along a part of the reality. If the program of Realists was to lift the veil of legal Form to reveal living essences of power and need, the program of the Critics is to lift the veil of power and need to expose the legal elements in their composition.

\section{B. Law as Constitutive of Consciousness}

Many Critical writers would, I think, claim not only that law figures as a factor in the power relationships of individuals and social classes but also that it is omnipresent in the very marrow of societythat lawmaking and law-interpreting institutions have been among the primary sources of the pictures of order and disorder, virtue and vice, reasonableness and craziness, Realism and visionary naiveté and of some of the most commonplace aspects of social reality that ordinary people carry around with them and use in ordering their lives. To put this another way, the power exerted by a legal regime consists less in the force that it can bring to bear against violators of its rules than in its capacity to persuade people that the world described in its images and categories is the only attainable world in which a sane person would want to live. "Either this world," legal actions are always implicitly asserting, "some slightly amended version of this world, or the Deluge."

A familiar example of the way in which legal categories affect social perceptions would be the carryover into common speech and perceptions of the legal distinction between Public and Private realms of action, the Public being the sphere of collective action for the welfare of all through the medium of government (and thus the only realm of legitimate coercion), and the Private being the sphere of individual self-regarding action. ${ }^{15}$ Those who have internalized this distinction as part of the natural order of things, as all of us have

115. For representative Critical treatments of the Public/Private distinction as it has been applied to specific areas of law, see the articles by Paul Brest, Gerald Frug, Morton 
to some extent, are perfectly capable of deriving from it conclusions such as this: It is an invasion of the privacy and autonomy of a (private) corporation for (public) OSHA inspectors to come upon its premises without a warrant, but the same company's management can post time-study monitors in the workers' washrooms because the workers have (impliedly) consented to this in advance by private contract.

I don't for a moment mean that this particular set of conclusions-in which readers are bound to recognize the classic late nineteenth century mind-set, recently dusted off for revival-flows inexorably from the Public/Private distinction. One could certainly also conclude, as many people have, that corporations, being organized collectives endowed by law with effective coercive power over people within their jurisdiction (on their property), are like states and may therefore exercise their power only through politically accountable forms. ${ }^{16}$ The crucial point here is that both sets of conclusions are inferred from the same Public/Private classification (coercive-collective states vs. freely choosing individuals) that sets fairly severe limits on the ways in which we can imagine the world and how to change it. ${ }^{117}$

Let me try another, perhaps slightly less abstract, example which I hope might illuminate some of the differences between functionalist and Critical styles of historical explanation. A nineteenth-century state that we'll call "Wisconsin" enacts a "Iumber-lien" law-that is, a statute giving loggers of wood a priority lien for their wages in the proceeds from the sale of cut timber. ${ }^{118}$ How might an historian approach the interpretation of this bit of law? ${ }^{119}$ A good straightforward functionalist approach would look for the context of a social "problem" to which the law was an attempted response or solution.

Horwitz, Duncan Kennedy, and Karl Klare in the recent Pennsylvania Law Review Symposium on the Public/Private Distinction. 130 U. PA. L. Rev. 1246 (1982).

116. See, e.g. W. O. Douglas, Democracy and Finance (1940); Berle, For Whom Corporate Managers are Trustees: A Note, 45 HARv. L. Rev. 1365 (1932); Berle, Constitutional Limitztions on Corporate Activity- Protection of Personal Rights from Invasion Through Economic Power. 100 U. PA. L. REV. 933 (1952).

117. Indeed the separation of law from society in what I have called the dominant vision of legal scholarship is itself a product of the Public/Private distinction. No matter how much Realist and post-Realist scholars blur the distinction in their empirical work on the "law in action," they usually end up reasserting it when they describe the "limits of effective legal action." See text accompanying note 26 supra.

118. As the choice of this example probably reveals, it was developed in conversation with Willard Hurst.

119. The following paragraph is not my proposed history of the log-lien law but merely a sketch of how one might approach the task of interpreting its history. 
Let us suppose that our functionalist historian finds such a problem in the circumstance that logging enterprises were short of liquid capital out of which to pay wages but needed to attract labor into the forests for a long winter's work. The solution to this problem was to give some additional security for wages in the lien, which was somewhat easier to enforce legally and less subject to trumping by other claims than was an ordinary action for breach of contract. There is nothing wrong, it seems, with this explanation as far as it goes. But then one starts to wonder: Why this solution rather than others one could think of-others that were actually adopted in nearby times and places? Here's a quick offhand list of potential solutions that doesn't even begin to exhaust the possibilities: (1) use slave labor in the forests; (2) use conscript labor-either as part of compulsory militia service or as a statutory duty of every able-bodied man in the state; (3) raise the capital fund for wage payments out of taxes; (4) refuse to "intervene in the private contracts" between logger and employer, and let the loggers contract, if they can, for their security interest in the wage bargain; (5) run logging as a state enterprise, paying loggers out of general revenues or out of an excise.tax on log sales; (6) make the loggers general partners in the enterprise, entitled to manage company concerns and to share in company profits. In the perspective created by some of these alternatives, the lumber-lien law appears to have been the product of a political consciousness in which, for example, "enterprise" was "private," though the state might be expected to help it out and even "regulate" a bit, and in which labor was "free" but definitely subordinate. The main point I want to make here is that this statute was not only the product of such a consciousness but helped to reproduce that consciousness by confirming it. The statute's enactment made some political alternatives that the society had already discarded as bad or unworkable (slavery, conscription, state enterprise) just a tiny bit more unthinkable and made it a tiny bit more difficult to imagine something altogether outside the scope of familiar possibilities (such as the option of laborers as equal partners). In short, the legal forms we use set limits on what we can imagine as practical options: Our desires and plans tend to be shaped out of the limited stock of forms available to us: The forms thus condition not just our power to get what we want but what we want (or think we can get) itself. ${ }^{120}$ This perspective com-

120. I have no reason, incidentally, to think that Hurst himself would disagree with this analysis, since his work has always been devoted to showing how lawmakers' notions of the practical and functional have been shaped and constricted by the basic categories of their 
pletely collapses the distinction that legal writers sometimes makethat indeed I made earlier in this article when discussing the Variations-between "instrumental" and "symbolic" uses of law. One never has more power than when one has so successfully appropriated the symbols of authority that one's actions are not seen as exercises of power at all, but simply as expressions of sound pragmatic common sense. ${ }^{121}$

Another way of looking at what seems to be the key difference of approach between functionalists and their Critical opponents is that the functionalist examines what has actually happened and explains how it all "works," how each development fits into the pattern created by all the others, while the Critic takes each event as situated not on a single developmental path but on multiple trajectories of possibility, the path actually chosen being chosen not because it had to be but because the people pushing for alternatives were weaker and lost out in their struggle or because both winners and losers shared a common consciousness that set the agenda for all of them, highlighting some possibilities and suppressing others completely. How can one identify the counterfactual trajectories, the roads not taken? From the experience of other societies, from the hopes of those who lost the struggle, from routine practices that the same society has tried in other spheres of life without ever dreaming they

political consciousness. I think the important difference between him and the Critics is something like this: He takes the consciousness of nineteenth-century lawmakers-consisting of such elements as distrust for executive authority, faith in the market, a Promethean urge to dominate nature. etc.-as the product of a liberal, middle-class mind-set forged in European historical conflicts of the seventeenth and eighteenth centuries, and pretty much fixed since then. To express this perhaps rather too grandly, for him. consciousness ceases to have a history after it reaches the American shore; it has only a series of instantiations. The view of many Critics. on the other hand, is that: (a) no political consciousness can persist simply because of inertia; enormous energy and effort (though rarely, to be sure, fully self-conscious effort) must be poured into reproducing it and protecting it from competition and disintegration: (b) in any case, the content of the basic American liberal ideology has not been constant over the last two centuries, but has undergone important transformations; and (c) even in what appear to have been its moments of greatest stability and most widespread consensual adoption, the liberal ideology was shot through with so many contradictions, so many implications leading the society in opposing directions, that the maintenance of consensus cannot be explained simply by the dominance of that ideology. These Critics see their task as explaining how the basic political ideology, the unexamined background common sense of the time, was reproduced and transformed and its centrifugal tendencies kept under control: and they see legal forms and practices as central to these processes. In a nutshell, Hurst sees law as a product of an ideological consciousness applied to practical problem-solving; the Critics see law as a primary producer of that consciousness. The difference is partly one of emphasis, of diverging views of what most urgently needs explaining.

121. See S. Llkes, Polver: A Radical View (1974). 
might be applied to the situation at hand, and from imagination disciplined, as one hopes, by the knowledge of past failures.

I take Karl Klare to be practicing something like this method in his history of the conservatizing Supreme Court interpretations of the Wagner Act. ${ }^{122}$ Klare has been criticized for seeming to assume that the Wagner Act was radical legislation to start out with. It was, say his critics, as mildly reformist (or, if you prefer, designed to coopt) in inspiration as in later interpretation. ${ }^{123}$ To the extent that Klare's account is one of the corruption of a radical vision, the criticism has some bite. Yet the main problem with the criticism is that it takes for granted a single-trajectory view of historical change; it assumes that things must evolve along the path they start out on. In the case of legislation, this path is sometimes identified by a curiously Formalist method as the "intent" of the enacting legislature, as if that legal construct had both some definite substance and some privileged claim to set the course of history! Klare, however, situates the Wagner Act at the junction of myriad potential tracks of departure-one could identify some of these by the programs of labor leaders of the time, others by the experiments of labor movements elsewhere, and still others by the "corporatist" models being practiced in the major European states and in some American industries-and then shows how the Supreme Court decisions, informed by a pervasively held general postwar consciousness on how to secure the conditions of "industrial peace," systematically helped lead the society down one track rather than any of the possible others. ${ }^{124}$

122. Klare, Judicial Deradicalizalion of the Wagner Act and the Origins of Modem Legal Consciousness, 1937-1941, 62 MiNN L. REv. 265 (1978).

123. Comment, The Radical Potentzal of the Wagner Act: The Duty to Bargain Collectively; 129 U. PA. L. REV. 1392 (1981).

124. Another, and separate, issue raised by the article is whether any important part of the history of labor relations is revealed by Supreme Court opinions at all: Are these mandarin dictates not absurdly remote from the "real" world of labor struggles? I will try to deal with this issue in general terms, see notes 127-40 infia and accompanying text; for now, let me just say that Klare wouldn't claim to have done anything more than to explore a fractional contribution to the formation of conventional ways of thinking among the elites about "the labor problem." The Justices borrowed from, and thus hardened by their authoritative example, some of the prevailing mentalities of their time. In conjunction with hundreds of other acts of consciousness-formation, these set the agenda for the ways in which many decision-makers in that generation framed issues having to do with labor. If one wanted to expand on Klare's work, one could look for other manifestations of the mentality he describes on the Cour in other institutional settings, as well as for deviating and opposing mentalities. Kelman, Trashing. 36 STAN. L. REv. 293 (1984) contains a valuable speculative sociology of high-level legal doctrine. 


\section{Indeterminacy Located in Contradiction}

The partial critiques attack the twin determinisms of functionalism and evolutionism mostly by means of empirical counterexamples drawn from Legal Realism and the Law-and-Society movement in the case of functionalism (in practice, the effect of law varies enormously with differences of power politics, cultural predisposition to accept it, strength of local custom, etc.) and from comparative historiography in the case of evolutionism (there are many paths of development and of legal response; indeed variation in developmental path is partly a function of legal variation). Taken together, these partial critiques add up to the proposition that when you situate law in social context, it varies with variations in that context. Some of the most original and powerful recent Critical writing, however, carries the claim of law's indeterminate relation to social life a significant step further. The same body of law, in the same context, can always lead to contrary results because law is indeterminate at its core, in its inception, not just in its applicarions. This indeterminacy exists because legal rules derive from structures of thought, the collective constructs of many minds, that are fundamentally contradictory. We are, the theory goes, constantly torn between our need for others and our fear of them, and law is one of the cultural devices we invent in order to establish terms upon which we can fuse with others without their crushing our identities, our freedom, even our lives. One way, therefore, of writing the histories of legal systems is to examine successive attempts to build structures that will facilitate good and prevent bad fusion. Such histories can reliably be expected to exhibit two properties: First, because the structures have usually been built by dominant elites (though with input from those struggling from below), their content will be ideological. That is, their methods of sorting out good from bad interactions will contain a bias in favor of existing orders. Second, and more important because the fundamental contradiction between the needs for fusion and for individuality has never been (perhaps can never be?) overcome, legal structures represent unsuccessful and thus inherently unstable mediations of that contradiction. Over time, therefore, these legal structures will tend to become unglued and to collapse.

According to this vision, modern American legal history is in part the story of how the latest of these great cultural constructs, "liberal legalism," arose and developed its own characteristic set of mediating devices (chief among these being the division of social life into a private sphere of contracting individuals, e.g., "the market," and a 
strictly limited sphere of constitutional/democratic collective coercion, "the state"); how the construct was purified of its preliberal elements and elaborated to its highest pitch in the late nineteenth century; and how, at the moment of its perfection, it started to decay under attacks from without and the pressure of its own internal contradictions-ultimately leaving us where we are now, living in its ruins, no longer believing in its mediating powers, and clinging to it still because we have found nothing to replace it, and being faithless moderns, doubting that we ever can. The general framework of this story has served as the background to a growing number of histories of particular bodies of legal doctrine and theory, each of which locates its special set of rules and principles within the fundamental contradiction and shows how one attempt after another to mediate that contradiction results in failure. ${ }^{125}$

The common thread of these histories is the observation that the contradiction makes available for the decision of every case matched pairs of arguments that are perfectly plausible within the logic of the system but that cut in exactly opposite directions. The managers of the legal system preserve their sense that law is actually relatively orderly and predictable by assembling a bunch of devices to keep these oppositions from becoming too starkly obvious (even to themselves). They classify sorne of the oppositions as "anomalies and exceptions." They stick others in separate categories (e.g., law/equity). They rule out still others (the capitalist wage-bargain is invalid, at least in times of high unemployment, because concluded under duress; the equal protection clause prohibits rationing scarce social goods by ability to pay) by a separation between law and politics or simply by arbitrary ideological fiat (interpretations of rules that would too much alter the status quo are wrong per se). Nonetheless, these fudging devices are subject to strains that eventually crack them apart. Enemies of the status quo expose obviously ideological

125. Kennedy, The Struclure of Blackstone's Commentaries, 28 Buffalo L. REv. 205 (1979), the pioneer venture in this mode, may be said to have founded an entire school. See e.g., Kainen, From Vested to Substantive Rights, 31 BufFalo L. Rev. (1982); Olsen, The Family and the Market: A Study of Ideology and Legal Reform, 96 HARv. L. Rev. 1497 (1983); Singer, The Legal Rights Debate in Analytical Jurisprudence from Bentham to Hohfela', 1982 WIS. L. REV. 975; Vandevelde, The New Froperty of the Nineteenth Century: The Development of the Modem Concept of Property, 29 Burfalo L. Rev. 325 (1980); Note, Tortious Interference with Contractual Relations in the Nineteenth Century: The Transformation of Property, Contract, and Tort, 93 HARV. L. REV. 1510 (1983)

For those unfamiliar with the method, an introduction to it notable for its lucidity and cleanness of line is Elizabeth Mensch's essay on contract law as a mediator between the contradictory desires to promote freedom of action and to guarantee the security of expectations. See Mensch, supra note 53. 
contrivances for what they are and develop arguments based on utopian counterpossibilities of the system. ("Freedom of contract" as administered is just the rule of the stronger; contracts can't be really free unless entered into by parties with "equal bargaining power"; hence, "freedom of contract" norms require regulatory schemes equalizing bargaining power.) Ordinary lawyers and judges with no wish whatever to destroy the system lay bare its contradictions in adversary arguments or dissents. And jurists whose main ambition is to justify the system by showing how clear and orderly it is at its core end up expounding it so well that its faults appear in plain view. ${ }^{126}$

Anyone who has come to adopt this approach has left functionalism far behind. For if it turns out to be true that law is founded upon contradictions, it cannot also be true that any particular legal form is required by, or a condition of, any particular set of social practices. And, in fact, one of the skills that the fans of this method have developed to an abnormal extent is that of supplying, whenever they hear a claim of functional relation between a legal rule and a social practice, the standard counterclaim, with counterexamples, for an exactly inverse relationship.

\section{Criticizing the Critics: Some Points of Controversy}

One of the melancholy truths about Critical Legal Studies generally seems to be that its students, although many of them try hard to write free of jargon for wide audiences, have for the most part not succeeded in communicating their ideas clearly enough to attract much relevant criticism from outside opponents. Most of the interesting controversies that I've become aware of have taken place within CLS, among people who consider themselves part of the movement. I will devote the space remaining here to a brief account of some of these controversies and will scatter remarks here and there to indicate where I stand on them. These controversies tend to swirl around the validity of the approach described in the last section: legal historiography as the intellectual history of the rise and fall of paradigm structures of thought designed to mediate contradictions. ${ }^{127}$ This special kind of doctrinal history is surely the most dis-

126. It would be inconsistent with the Critics' inclination to relativize all historical stories for them to claim any privileged status for their own, and they don't. Their story is, presumably, as time-bound in its assumptions and as subject to displacement by other, more persuasive stories, as any other historical account.

127. Again, this is by no means the only way in which Critics write history. Every type of partial- or extended-Critical mode that I've mentioned in this piece has defenders and adherents; and the chief rival to the intellectual-history-of-doctrinal-contradictions approach 
tinctive Critical contribution, as well as the one that has caused most of the arguments.

\section{A. Argument \# 1: "The history of DOCTRINE?" This is the big liberating move? You've got to be kidding!"'}

This argument is more complex than first appears and usually turns out to consist of several different points:

(1) "You're just doing the history of legal ideas; what we need is the history of the law's effects on actual behavior in the real world." This point I think has been sufficiently addressed already: It's another version of the false law/society dichotomy. "The economy" is no more "real" than "legal ideas." It's an assemblage of conventions of which "legal ideas" such as property, contract, promissory and fiduciary obligation, not to mention money itself, are indispensable elements and propagators.

(2) "But assuming that you're right, that the Material is inextricably mixed up with the Ideal, isn't all this doctrinal history still excessively Idealist? For one thing, it seems so abstract and bloodless, so far removed from the world of concrete social experience. For another, the method makes it look as if the history of these legal/intellectual structures were somehow self-determining-as if the structures rose and fell because of some objective inner dynamic unrelated to the world of social struggle or, for that matter, to real people of any kind. Doesn't this just substitute another set of evolutionary determinisms for the social evolutionism that it rejects?"

This point is troubling, though it is perhaps more about appearance than about substance. It's true, I think, that the kind of structuralist historiography that some of the Critics have written sometimes reads as if these impersonal structures had a life of their own and human beings were enslaved to the needs of that life-cycle, building or demolishing as the World-Spirit might dictate. This appearance is quite unfortunate because I don't believe that these Critics want to divorce the life-cycle of their structures from human agency. On the contrary, their point is that people build these systems to satisfy their needs for cooperation with, while protecting against their terror of, one another. As people build, they reify, attributing to their own creations an impersonal determining force

is probably the history-from-the-bottom-up account of oppressed groups struggling against ruling-class versions of law and for their own versions, inspired mainly by the brilliant example of E.P. Thompson's work. See E.P. ThOMPSON. The MAKing OF THE ENGLish WORKING Class (1963); E.P. ThOMPSON, supra note 88. 
("the logic of freedom of contract requires that legal lines be drawn strictly limiting the state's power to affect the substantive terms of the bargain"). But the Critics, far from believing that these structures determine everything, spend all their time showing how indeterminate they are-how they always lead to contradictory consequences. What the structures "determine" is not any particular set of social consequences but the categories of thought and discourse wherein political conflict will be carried out.

If you accept, or at least are willing to listen sympathetically for a moment to this defense of the structuralist method, you'll see why it would be hard for the Critics to do as their opponents ask-to tie in the story of the rise and fall of structures to narratives of particular social struggles between concrete interests. The Critics are trying to describe something that partly transcends concrete interest because it helps create the conceptual universe shared by all parties to the struggle. What the parties are struggling over is the power to interpret and to have applied in their favor the (contradictory) implications of a common set of premises. For example, because most of the actual work of elaborating the basic terms of political discourse is done by people at the top of the social pyramid, a historian would, to a limited extent, be able to tell the story of the rise of a structure as an elite's attempt to rationalize elite privileges and the story of its fall as the collapse of the elite's Empire of Reason under siege from the enemies below. Thus, the "classical" legal thought of the late nineteenth century was the creation of elite, mostly Republican or conservative Mugwump, lawyers and judges. The critiques that exposed it as ideology did often originate in reform movements considerably to the left of that elite (left-wing urban Progressivism, academic left-liberalism, Populism, the social-planning wing of the New Deal), which were expressing interests and programs of classes and groups somewhat further down in the social structure. Yet, as this particular example vividly demonstrates, such a simplistic narrative would be incomplete and fundamentally misleading if it cast elite conservatives as the sole architects of ideological mystification and their (relatively) left-wing critics or representatives of lower social classes as the bearers of Critical truth. Such an account would obscure the extent to which leftists and lower social classes shared the basic premises of the ideological structure. And it would obscure the role that elite conservatives themselves - think for example of Holmes, hardly a social reformer!--played in the demolition of that structure.

Nevertheless, the structuralist historians are partly to blame for 
the ways in which their work has been misunderstood. They do sometimes write the driest possible Ideengeschichte of doctrinal concepts evolving and dissolving over time, without paying nearly enough attention to the applications to which these doctrines were put in everyday practical reasoning or to the specific controversies or political events that suddenly opened up the doctrines to question. The structuralists would, I think, again respond that legal structures, because of their indeterminacy, can't be expected to connect in any predictable fashion with the interests of any particular class or group. Thus, a writer couldn't put the history of structures in the context of political events in any way that would make a coherent narrative. "Consideration" doctrine, for example, has played some part in building Anglo-American private law structures, ${ }^{128}$ but it would be hard to attribute developments in the doctrine very convincingly to any one side's political interests. ${ }^{129}$ (Nobody would write: "Agrarian radicals called for popular takeover of the banks and immediate abolition of the Pre-Existing Duty Rule.") One could concede this point to the structuralists and still ask them to embed their story in a narrative context that would at least supply subjects and occasions to the narrative to show that it is human beings with reasons and motives, not disembodied Spirits, who drive the manufacture of legal concepts: Who pushed which arguments on what occasions and why? What happened to set off the arguments? What happened to destabilize previously stable conventions? ${ }^{130}$ We ought to have a rule of style: no sentence without a subject; no intellectual move without a reason-even if the particular subject and reason may sometimes be largely incidental to the grander thematic history of legal consciousness. ${ }^{131}$

128. On the "latent functions" of consideration, see, e.g., D. DAvis, ThE Problem of SLAVERY IN THE AGe OF ReVOlUtion 1770-1823 (1975).

129. This does not mean, although the people I've called the disengaged think it does, that "consideration" doctrine has no social importance and should be treated solely as a piece of legal esoterica; the structuralist approach says that it matters all right, not all by itself, to be sure, but as a piece of a structure, a complex cultural code.

130. Joseph Singer does this contextualizing very usefully. For example, in the middle of an extremely abstract history of modern analytical jurisprudence, he uses the context of the law of labor injunctions to show why it might matter to anyone whether "rights" entailed correlative "duties" or not. Singer, supra note 125, at 989. A model for this sort of approach to intellectual history is Q. SKINNER, The Foundations of MOdern Political. THOUGHT (1978), which takes ancient arguments on authority, its legitimate exercise, proper limits, and redress for violating those limits, etc. through the successive political crises and controversies in which the arguments were deployed, warped, bent out of shape, and finally completely recast by the strategies of the disputants.

131. When I say "subjects," it should be clear that I don't just mean individual subjects; 
(3) "All right then, I can see why you want to write legal history as the history of legal consciousness, and I can even understand why you think that, although that history is made by real people in social life, it can be told without reference to pressures of immediate interest. But what I can't understand is why you chose to write about these particular forms of legal consciousness-case law and treatise literature produced by the high mandarins of the legal system-in the first place. After all, isn't part of your theory that everyone in society-not just lawyers and certainly not just jurists and appellate judges-produces, applies, and interprets 'law.' And isn't it therefore perverse of you to stick with the mandarin materials beloved of the most reactionary of Formalists?"

This is not an easy criticism to answer, but as a start I might say that I've never heard any Critic argue (as some traditional legal historians have been known to do) that Critical histories ought to focus exclusively on mandarin materials. But for an historiographical practice just setting off on its travels, the choice of these materials does make a certain amount of sense for several reasons. First, case law and treatises are relatively accessible. Thus you don't have to do a lot of digging to get materials to practice the method on, and newcomers, your students for example, can learn the method and produce finished pieces of research in a reasonable time. (In a field like law, which doesn't give people a long dissertation period to do research and develop their ideas, this is a real advantage.)

Second, the mandarin materials are among the richest artifacts of a society's legal consciousness. Because they are the most rationalized and elaborated legal products, you'll find in them an exceptionally refined and concentrated version of legal consciousness. Moreover, if you can crack the codes of these mandarin texts, you'll often have tapped into a structure that isn't at all peculiar to lawyers but that is the prototype speech behind many different dialect discourses in the society. ${ }^{132}$ For one example, the elite legal thought of the late nineteenth century ("classical" legal thought, as it's some-

legal concepts are made collectively, and the makers may be officials, judges, subcultures of professionals or intellectuals, the ideologues of political factions, workingmen's associations, religious groups, heavy-industry board chairmen, mass movements, or other collectives of whose existence our limited categories have left us unaware.

I am uneasy about this formulation even as I utter it. My colleague Tom Heller has vigorously argued that my attachment to narratives with subjects is a sentimental reaction to a prestructuralist past. For his reasons in detail, see Heller, Siructuralism and Critique, 36 STAN. L. REV. 127 (1984).

132. M. TUSHNET, supra note 101, exposes such a structure. 
times called) is strikingly parallel in its basic structure to classical political economy. ${ }^{133}$ For another, the transformations in the structure of legal thought which eventually led to Realism and the legal ideology of the administrative state have very close analogues in the rise of institutional economics. ${ }^{134}$ But the crucial question is whether studying elite legal thought will equip you only to study other elite dialects or whether it will also help you understand the vernacular, the common forms of legal discourse. It would take a lot of nerve to answer this with much confidence because I know of very few attempts so far to apply the structuralist method to legal discourse at the field levels of lower-order officials, practitioners, or private lawmakers, but it seems plausible to suppose that the method would work at that level also. ${ }^{135} \mathrm{My}$ guess is that field-level studies would reveal a lot of trickle-down effects-a lot of mandarin ideology reproduced in somewhat vulgarized forms, ${ }^{136}$ and doubtless also mixed up with a lot of foreign elements (as nineteenth-century American labor organizers, for example, assimilated the mainstream ideologies of their culture but mixed them up with elements less often found at the elite levels-evangelical religion, precapitalist ideas of work, time, and community, and some solidarist strains of European socialism $^{137}$ ). Actually, these effects may not be trickle-down effects at all, but rather refracted trickle-up effects. That is, the mandarin ideology may represent simply an elaborated, purified, and formalized version of a consciousness whose primary producers are to be found all over the society. If either of these suppositions is even partially correct, regardless of the actual directions of influence, people interested in

133. See P. ATIYAH, supra note 53, at 660-69; Balbus, Commodity Form and Legal Form: An Essay on the "Relative Autonomy" of the Law, 11 L. \& Soc'Y REV. 571 (1977).

134. See Heller The Political Economy of American Federalism, in EUROPEAN INTEGRATION in THE Light of the American Federal Experience - (M. Cappelletti ed. 1984) (forthcoming).

135. See, e.g., Simon, Legality, Bureaucracy and Class in the Welfare State, - YALE L.J. (1983) (forthcoming) (structural analysis originally developed in context of private law doctrine applied to study of lower-level welfare bureaucrats); see also J. REID, LAW FOR THE Elephant: Property and Social Behavior on the Overland Trail (1980) (basic elements of formal legal rules of property and contract internalized by laypeople and routinely applied in contexts remote from officials and courts); Katz \& Teitelbaum, PINS Jurisdiction, the Vagueness Doctrine, and the Rule of Law, 53 IND. L.J. 1 (1977-78) (disposition of juvenile offendens); Weisberg, Deregulating Death, 1983 SuP. CT. REv. 303 (1983) (counsels' arguments to juries in death cases).

136. The common speech of practically-minded people, as Keynes famously remarked, is often composed largely of the theories of long defunct intellectuals. J. KEYNES, GENERAL THEORY OF EMPLOYMENT, INTEREST AND MONEY (1936).

137. See, e.g., H. GutMAN, supra note 74, at 3-117 (1976); D. MONTGOMERY, BEYOND EQUALITY: LABOR AND THE RADICAL REPUbLICANS 237-41 (1967). 
popular legal consciousness would be making a serious mistake to ignore studies of elites.

Third, in the particular context of the law schools, it has made good strategic sense for Critics to focus their energies on the deconstruction of mandarin materials because their method gives each other and their students alternative ways of thinking about the very materials that law teachers have traditionally cared about: the core doctrinal subjects of the first year curriculum. Although the Lawand-Society movement tried for years to convince traditional law teachers that these core subjects were "irrelevant" because they didn't "have anything to do with the real world," it had very little effect on the teaching and writing that went on in law schools. The Critics, by contrast, have engaged traditional doctrinalists on their own turf and have in the process stirred up a fabulous ruckus. My guess, however, is that this strategic usefulness will not last much longer; I predict that the forces of the orthodox will simply abandon their traditional doctrinal ground to the Critics, claiming that "it doesn't matter anyway, because it doesn't have anything to do with the real world." Empirical arguments, which used to be the stock in trade of left-liberal reformers trying to expose the gap between legal principles in high-sounding pretension and in seamy operation, will increasingly be heard from conservatives claiming "there's no evidence" that elite legal ideology affects anyone's "behavior." Simple anti-intellectualism, the claim that all these academic debates over doctrine are doubtless fascinating to the Rapunzels of the ivory tower but irrelevant to the practical tasks of lawyering, will also be adopted by these conservatives. When this happens, the Critics will have to find new ways of bringing home to mainstream lawyers the historicity and ideological nature of those lawyers' ordinary ways of thinking, and this need will force the Critics to try to decode the vernacular.

The Critics should try to do that anyway. I love the work that the Critical doctrinal historians have been doing. I think it's among the most exciting intellectual work being done anywhere and that it has revolutionized our vision of our legal past. But I also think that, just as the Critical narrative mode of intellectual history has misled readers into supposing that the Critics have bought into the idealism of the old Formalists who thought that legal ideas just "evolved" according to some mysterious inner dynamic, its focus on mandarin materials has led readers to suppose Critics to be trapped in the old Formalist belief that only specialized-law-stuff-separate-from-politics 
is law. My point is-and I hope this piece has been persuasive-that the Critics don't at all think that way about law. As E.P. Thompson has said about his own work,

I found that law did not keep politely to a "level," but was at every bloody level; it was imbricated within the mode of production and productive relations themselves (as property-rights, definitions of agrarian practice) and it was simultaneously present in the philosophy of Locke; it intruded brusquely within alien categories, reappearing bewigged and gowned in the guise of ideology; it danced a cotillion with religion, moralizing over the theater of Tyburn; it was an arm of politics and politics was one of its arms; it was an academic discipline, subjected to the rigor of its own autonomous logic; it contributed to the definition of the self-identity both of rulers and of ruled; above all, it afforded an arena for class struggle, within which alternative notions of law were fought out. ${ }^{138}$

Specialized elites may exercise a disproportionate influence on the manufacture of the forms that go into the constitution of legal relations, but the forms are manufactured, reproduced, and modified for special purposes by everyone, at every level, all the time. Critics are not going to get this insight across if they don't switch their focus. ${ }^{139}$

138. E. P. THOMPSON, THE POVERTY OF THEORY 96 (1978).

139. Some examples of what research into legal consciousness at the field level might yield are already available. Leon Litwack's study of Southern planters' relations with their newly emancipated slaves after the Civil War contains a wealth of evidence of how both planters and freedmen thought about (legal) "freedom" and "property" and "contract" and of how they tried to put their ideas into practice. For instance, Litwack describes in thorough detail the kinds of contracts that planters used to bind their freedmen to the land, how planters, freedmen, local courts, and the Freedmen's Bureau interpreted those contracts, and what all sides thought about them. He shows, in short, the social/legal relations of contract labor in the very act of their manufacture. L. LITwACK, BEEN IN THE STORM So LONG: THE AFTERMATH OF SLAVERY 336-449 (1979). William Sewall's study of French labor movements in the early nineteenth century shows how French workers carried forward from the Ancien Regime various ideas of workers' "corporations" founded on a sense of craft communities and how, in the throes of successive political and economic crises, post-Revolutionary movements converted these traditional ideas into republican, and then revolutionary, ideologies of solidary corporate association. This is, in effect, a study of the social/ideological content of the legal form of the "corporation" from a new angle, the angle of those who borrowed some of their forms and practices from their rulers but refashioned and combined them with forms of their own to suit their own purposes and special view of their situation. W. SEWALL, WORK and ReVolution in France: The Language of Labor from the Old Regime To 1848 (1980). And Michael Burawoy's extraordinary participant observation study of a modern industrial factory exposes the microscopic detail of the processes that engage the workers' consent and loyalty to the way the work place is managed. One of the many sets of such processes are those of what he calls the "internal state," the plant's internal equivalent (grievance procedures and collective bargaining) of the "rule of law" in the wider societyapparently impersonal institutions through which workers are granted a limited share in governing and to whose rules all the "citizens" of the plant, workers and management alike, are 
There are already signs of such work being done within Critical Legal Studies, ${ }^{140}$ and more is doubtless to come. The more, the better, not because workers' or freedmen's consciousnesses are somehow more "real" than Samuel Williston's consciousness (that belief is a sentimentalization that obscures how much the consciousness of all these people springs from the same cultural taproots) but because we'll never understand the power that legal forms hold over our minds unless we see them at work up close, in the most ordinary settings.

\section{B. Argument \#2-The Critics who do intellectual-history-of-doctrinal- structures haven't got any theory of the causal relations between legal/doctrinal change and other social change, except their claim that the contradictions within legal structures make such relations completely indeterminate. But this claim of indeterminacy is surely exaggerated - there are lots of regularities in legal/social relations}

This argument has to be broken down a bit to be responded to. I think that, at this stage, the response can be very short because much of it has been answered already. It's true that, for example, the Critics have not produced an analysis along the lines of the traditionalist functionalist histories or of instrumental Marxism that relates changes in the legal system to changes in the economy. The whole point, recall, of the Critics' critique is that the "economy" isn't something separate from the "law," which reacts on law and is in turn reacted upon by it; the idea of their separation is a hallucinatory effect of the liberal reification of "state" and "market" (or "public" and "private") into separate entities. Because the economy is partially composed of legal relations, legal and economic histories are not histories of distinct and interacting entities but simply different cross-cutting slices out of the same organic tissue. Again, if the Crit-

expected to adhere for the common good. M. BURAWOY, MaNufacturing ConSENT: Changes in the Labor Process under Monopoly Capitalism 109-20 (1979).

140. D. Kennedy, Legal Education and the Reproduction of Hierarchy: A Polemic Against THE SYSTEM (1983), for example, is a brilliantly described polemical anthropology of the micro-society of American law schools, which argues that the micro-society's patterns of hierarchy reproduce and thus reinforce similarly structured patterns of hierarchy in other social "cells". Elizabeth Mensch, The Colonial Origins of Liberal Property Rights, 31 BUFFALO L. REV. 635 (1982) is a study of the practical applications of ideologies of legal property-relations at all levels of colonial New York society, from the highest and most abstract level of general political theory, through mandarin legal doctrine, down to the most commonplace contexts of iegal/political disputes. 
ics want to make this point convincingly, they will have to start slicing their narratives out of field-level uses of law.

The other argument rests, I think, on a misunderstanding of what the Critics mean by indeterminacy. They don't mean-although sometimes they sound as if they do-that there are never any predictable causal relations between legal forms and anything else. As argued earlier in this essay, there are plenty of short- and mediumrun stable regularities in social life, including regularities in the interpretation and application, in given contexts, of legal rules. Lawyers, in fact, are constantly making predictions for their clients on the basis of these regularities. The Critical claim of indeterminacy is simply that none of these regularities are necessary consequences of the adoption of a given regime of rules. The rule-system could also have generated a different set of stabilizing conventions leading to exactly the opposite results and may, upon a shift in the direction of political winds, switch to those opposing conventions at any time.

\section{CONCLUSION}

As this guided tour comes to an end, what shall we say about the contribution of the Critical historians? Perhaps this: that they have added powerfully to the critique of the functionalist-evolutionary vision that has so long dominated legal studies and that they have produced their own distinctive and exciting brand of doctrinal historiography and successfully taught others how to apply their method. The Critics are still a long way from being able to deliver the brightest promises of their Critical program: thickly described accounts of how law has been imbricated in and has helped to structure the most routine practices of social life. But they are trying; they are getting there. 